\title{
Are Fc Gamma Receptor Polymorphisms Important in HIV-1 Infection Outcomes and Latent Reservoir Size?
}

OPEN ACCESS

Edited by:

Ann Jones Hessell,

Oregon Health and Science

University, United States

Reviewed by:

Michael Anthony Moody, Duke Human Vaccine Institute,

United States

Christiane Moog,

Institut National de la Santé et de la Recherche Médicale (INSERM),

France

*Correspondence: Bright Adu

Badu@noguchi.ug.edu.gh George B. Kyei

gkyei@noguchi.ug.edu.gh

tThese authors have contributed equally to this work and share last authorship

Specialty section: This article was submitted to Viral Immunology, a section of the journal

Frontiers in Immunology

Received: 21 January 2021 Accepted: 06 April 2021 Published: 04 May 2021

Citation:

Lamptey H, Bonney EY, Adu B and Kyei GB (2021) Are FC Gamma Receptor Polymorphisms Important in HIV-1 Infection Outcomes and Latent Reservoir Size?

Front. Immunol. 12:656894. doi: 10.3389/fimmu.2021.656894
Helena Lamptey ${ }^{1}$, Evelyn Y. Bonney ${ }^{2}$, Bright $\mathrm{Adu}^{1 * t}$ and George B. Kyei ${ }^{2,3,4 * t}$

${ }^{1}$ Department of Immunology, Noguchi Memorial Institute for Medical Research, University of Ghana, Accra, Ghana, 2 Department of Virology, Noguchi Memorial Institute for Medical Research, University of Ghana, Accra, Ghana, ${ }^{3}$ Department of Medicine, Washington University School of Medicine in St Louis, St. Louis, MO, United States, ${ }^{4}$ Medical and Scientific Research Centre, University of Ghana Medical Centre, University of Ghana, Accra, Ghana

Fc gamma receptors (FcyR) are cell surface glycoproteins which trigger specific effectorcell responses when cross-linked with the Fc portions of immunoglobulin (IgG) antibodies. During HIV-1 infection, the course of disease progression, ART response, and viral reservoir size vary in different individuals. Several factors may account for these differences; however, Fc gamma receptor gene polymorphisms, which influence receptor binding to IgG antibodies, are likely to play a key role. FcyRlla (CD32) was recently reported as a potential marker for latent HIV reservoir, however, this assertion is still inconclusive. Whether FcyR polymorphisms influence the size of the viral reservoir, remains an important question in HIV cure studies. In addition, potential cure or viral suppression methods such as broadly neutralizing antibody (bNAbs) may depend on FcyRs to control the virus. Here, we discuss the current evidence on the potential role played by FcyR polymorphisms in HIV-1 infection, treatment and vaccine trial outcomes. Importantly, we highlight contrasting findings that may be due to multiple factors and the relatively limited data from African populations. We recommend further studies especially in sub-Saharan Africa to confirm the role of FcyRlla in the establishment of latent reservoir and to determine their influence in therapies involving bNAbs.

Keywords: FcyR polymorphisms, HIV-1 latent reservoirs, HIV-1 cure strategies, HIV-1 disease progression, broadly neutralizing antibodies

Abbreviations: ART, Anti-Retroviral Therapy; ADCC, Antibody-Dependent Cellular Cytotoxicity; ADCD, AntibodyDependent Complement Deposition; ADCP, Antibody-Dependent Cellular Phagocytosis; ADCVI, Antibody-Dependent Cell-mediated Virus Inhibition; bNAbs, Broadly neutralizing antibody; CD4 T cells, Cluster of Differentiation 4 T cells; CNVs, Copy Number Variations; DC's, Dendritic Cells; EC, Extracellular Domain; Fc $\gamma R$, Fc gamma receptors; FCGR, Fc gamma receptor gene; GPI, Glycosylphosphatidylinositol-anchored; HLA, Human Leukocyte Antigen; HIV, Human Immunodeficiency Virus; ITAM, Immunoreceptor Tyrosine-based Activation Motif; ITIM, Immunoreceptor Tyrosinebased Inhibitory Motif; IgG, Immunoglobulin; IC, Intracellular Domain; NK, Natural Killer Cells; SNPs, Single Nucleotide Polymorphisms; TM, Transmembrane Domain. 


\section{INTRODUCTION}

An estimated 37.9 million people are infected with the human immunodeficiency virus (HIV). The burden of disease is highest in sub-Saharan Africa, where approximately 25.6 million people live with the virus (1).

For most patients infected with HIV, antibodies elicited by the host immune system have limited potential to neutralize the virus. The result is a gradual decline of host CD4+ T cells leading to full blown acquired immune deficiency syndrome (AIDS) over time. Antiretroviral therapy (ART) is able to suppress the virus and reverse the decline in CD4 count in most patients. However, ART does not provide cure due to a stable latent reservoir established early in the infection process in resting CD4+ $\mathrm{T}$ cells, macrophages and other cells.

The course of HIV-1 infection, disease progression, ART response, and reservoir size vary in different individuals. For instance, long term non-progressors can maintain high CD4 count, and control the virus for up to 10 years without ART (2-4), compared to "rapid progressors" who develop full blown AIDS within 3-4 years of infection $(5,6)$. Then, there is the rare group of HIV-1 infected individuals called "elite controllers", who can maintain a viral load of less than 50 copies/ml without ART for even longer periods $(7,8)$. These elite controllers and long term non-progressors, have a smaller viral reservoir (9, 10). Viral factors such as deletions or mutations in key viral genes have been implicated in the differences in natural HIV control. Factors such as source of HIV infection, timing of ART and ethnicity have all been cited as potential determinants of viral reservoir size (11). However, host genetic factors such as human leukocyte antigen (HLA) and polymorphisms in Fc gamma receptor (FCGR) genes which influence the receptor binding to immunoglobulin (Ig) G antibodies are likely to be even more critical. Fc $\gamma \mathrm{R}$ gene copy number variations (CNVs) and/or single nucleotide polymorphisms (SNPs) could cause differences in Fc gamma receptor $(F c \gamma R)$ expression density on effector cell surface, binding affinity to IgG subclasses and signaling potential which would influence HIV-1 infection risk, disease progression and vaccine efficacy $(12,13)$. In this review, we summarize current knowledge on the role of FcyR gene polymorphisms and HIV-1 infection, in relation to ART outcomes and control of the viral reservoir. We will explore the idea that $\mathrm{Fc} \gamma \mathrm{R}$ polymorphisms could help explain the differences in HIV-1 infection outcomes, responses to ART and broadly neutralizing antibodies (bNAbs) and influence the size of the viral reservoir.

\section{OVERVIEW OF FC $\gamma R S$ AND THEIR ROLE IN HOST IMMUNITY}

Fc $\gamma$ Rs are cell surface glycoproteins that bind the Fc portions of different IgG subclasses to trigger different cell effector functions $(14,15)$. Fc $\gamma$ Rs are expressed on most immune cells including monocytes, natural killer (NK) cells, B cells, eosinophils, basophils, dendritic cells, platelets, macrophages, and some subpopulations of T cells (16-18).
There are three main classes of Fc $\gamma$ Rs namely Fc $\gamma \mathrm{RI}$ (CD64), Fc $\gamma$ RII (CD32) and Fc $\gamma$ RIII (CD16) each with different isoforms encoded by different genes (Figure 1). The Fc $\gamma$ RI family of receptors consist of 3 genes (FCGR1A, FCGR1B and FCGR1C) that share about $98 \%$ sequence homology and thought to flank the centromere of chromosome 1 at bands 1 p12 (FCGR1B) and $1 \mathrm{q} 21$ (FCGR1A and FCGR1C) (19). FcyRIA is the only known high affinity Fc $\gamma R$. It is expressed by monocytes, dendritic cells (DC's), macrophages and neutrophils (20) and plays a role in antibody mediated phagocytosis. The Fc $\gamma$ RII family of receptors have low binding affinity for IgG and are encoded by three genes (FCGR2A, FCGR2B and FCGR2C) located on chromosome 1q23.3 (16, 21). They are expressed on neutrophils, DC's, monocytes, B cells, NK cells, myeloid cells, and platelets. Fc $\gamma$ RII family of receptors do not use the common Fc $\gamma$-chain for activation (Fc $\gamma$ RIIa and Fc $\gamma$ RIIc) or inhibitory (Fc $\gamma$ RIIb) signaling because their Immunoreceptor Tyrosine-based Activation Motifs (ITAM) or Immunoreceptor Tyrosine-based Inhibitory Motifs (ITIM) are located directly in the intracellular cytoplasmic domain (22). The FcyRIIc gene is expressed on NK cells only with $13 \mathrm{Q}$ allele due to the glutamine (Q)/stop (STP) polymorphism at codon 13 located in the first extracellular domain $(23,24)$.

Fc $\gamma$ RIII family is encoded by 2 genes (FCGR3A and FCGR3B)

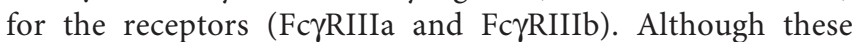
receptors are also low affinity binding, they can both bind efficiently to multimeric IgG and immune complexes. FcyRIIIa receptor can also bind with intermediate affinity and expressed on monocytes, tissue specific macrophages, dendritic cells, NK cells and gamma/delta T cells (21). The FCGR3B gene, encodes a glycosylphosphatidylinositol (GPI)-anchored receptor, which is highly expressed on neutrophils (25). These Fc $\gamma \mathrm{R}$ proteins bind to different IgG subclasses and regulate immunity by causing cell activation or inhibition depending on the receptors engaged (16). The mechanisms for Fc-mediated activities include antibodydependent cellular cytotoxicity (ADCC), antibody-dependent cellular phagocytosis (ADCP), antibody-dependent cellmediated virus inhibition (ADCVI), antibody-dependent complement deposition (ADCD), aggregation, and immune activation (26-28). They also induce cytokine production via their immune activating or inhibitory motifs (22). Thus FcyR polymorphisms may influence diverse effector functions such as cytotoxicity, phagocytosis, cytokine production, antigen presentation and degranulation and may contribute to the outcome of infections (29). For instance, in encapsulated bacterial infections, Fc $\gamma$ RIIa- $131 \mathrm{H}$ may be involved in efficient clearance of IgG2-coated particles since it has a higher binding affinity for IgG2 (30-32). Conversely, homozygous Fc $\gamma$ RIIa-131R genotype has been associated with severe forms of encapsulated bacterial infection $(30,31,33,34)$.

The allelic differences that affect $\mathrm{Fc} \gamma \mathrm{R}$ function are also important in host immune mechanisms against viral infections. FcyRIIa-131H/H homozygous infants were found to be more susceptible to perinatal HIV transmission (35) but in other studies no associations between FcyRIIa genotypes and HIV infection rates were noted (36), suggesting further 


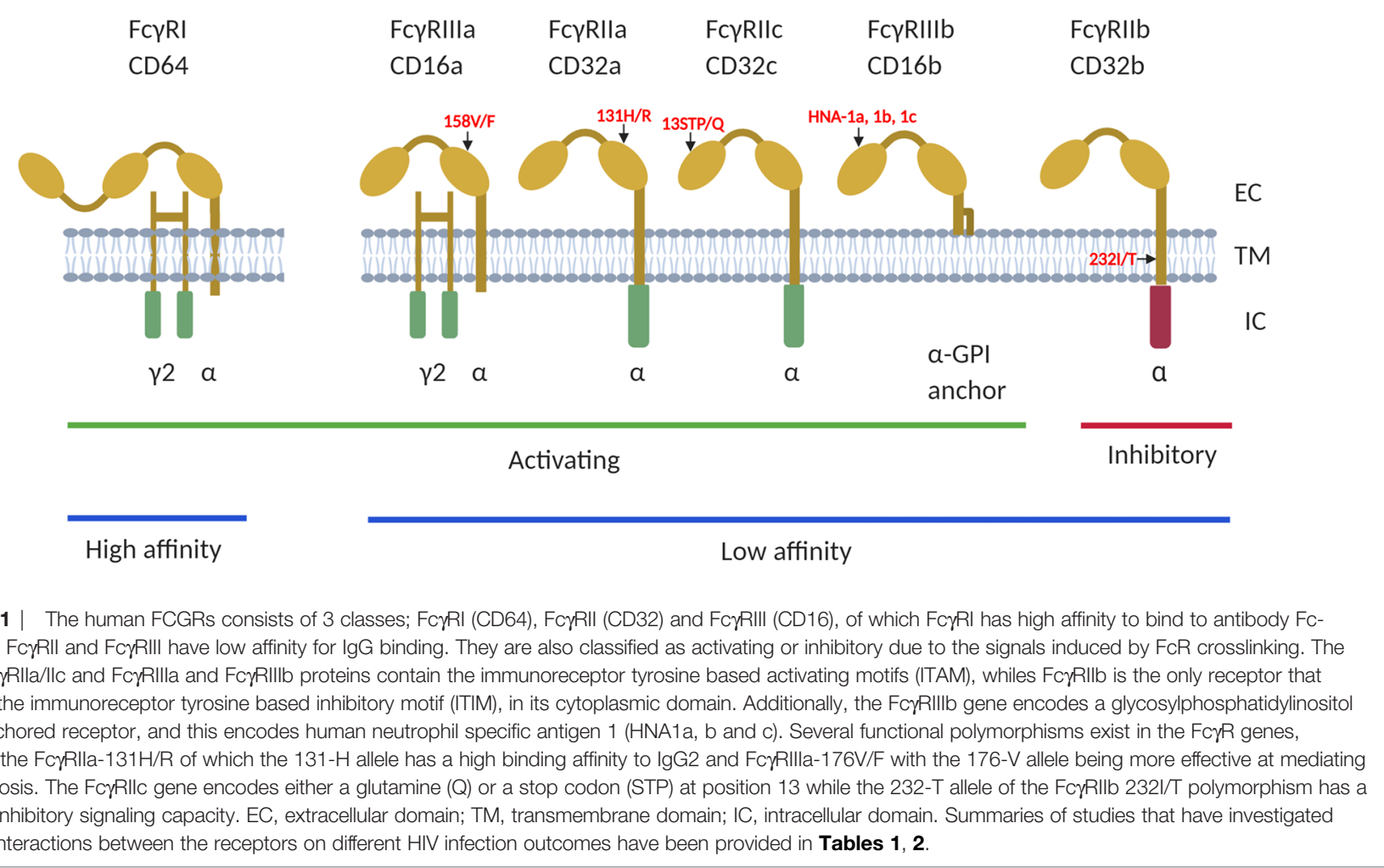

investigations are needed. In HIV-1 patients, Fc $\gamma$ RIIIa-V176F genotype is associated with the development of Kaposi's sarcoma and cryptococcal disease $(12,37,38)$. Other studies have implicated the FcyRIIa-R131 allele in Dengue (39-41), and other viral infections $(34,42,43)$. Fc $\gamma$ RIIb inhibits activation signals from activating FcyRs (18) and the FcyRIIb-232T allele elicits reduced inhibitory signaling and has been associated with inflammatory diseases (44), however, it has not been extensively studied in HIV (45). These studies show that different Fc $\gamma \mathrm{R}$ polymorphisms influence effector functions in diverse ways and subsequently impacts on infection outcomes differently (Table 1).

\section{FC $\gamma R$ POLYMORPHISMS AND THE RISK OF HIV-1 INFECTION WITH AND WITHOUT VACCINES}

Studies have not provided conclusive data on the association between FcyR polymorphisms and HIV-1 infection (56). For instance, contrasting results were reported when Fc $\gamma$ RIIa and Fc $\gamma$ RIIIa were examined with the risk of perinatal HIV-1 infection among infants in Kenya $(35,48)$. Whereas Brouwer et al., found that infant FcyRIIa-H131H (rs1801274) genotype was associated with susceptibility to perinatal HIV-1 transmission, Milligan and colleagues observed no such association with both Fc $\gamma$ RIIa and Fc $\gamma$ RIIIa. Rather, they observed that maternal Fc $\gamma$ RIIIa-V176F genotypes may lead to higher risk of mother to child transmission compared to the homozygous (V/V or F/F) genotype carriers. The differences in these results could be attributed to differences in the cohort design as well as statistical rigor (48). More work is needed to define the role of these genotypes in mother to child HIV-1 transmission. Such a study may involve using harmonized protocols in a multi-center recruitment of a reasonably large number of HIV-1 infected pregnant women, determining their $\mathrm{Fc} \gamma \mathrm{R}$ genotypes and monitoring their viral load throughout the pregnancy till birth. The HIV-1 infection status and Fc $\gamma \mathrm{R}$ genotypes of the child could then be determined to assess the genotype association with mother to child HIV-1 transmission.

A study that used samples from the European Multicenter AIDS Cohort Study (MACS), found an association between Fc $\gamma$ RIIa-131R/R genotype and a faster rate of CD4+ $\mathrm{T}$ cell decline and disease progression compared to individuals with the $\mathrm{R} 131 \mathrm{H}$ or $\mathrm{H} 131 \mathrm{H}$ genotypes (12). This may be due to the weaker binding of the $131 \mathrm{R} / \mathrm{R}$ receptor to $\operatorname{IgG} 2$ and IgG3 immune complexes. In-vitro experiments have shown that monocytes bearing this receptor do not efficiently internalize HIV-1 complexes, compared to $131 \mathrm{H} / \mathrm{H}$ receptors $(12,58)$. Furthermore, the expression of FcyRIIa on immune cells leads to the activation and production of proinflammatory cytokines, an indication that FcyRIIa-mediated T-cell activation would be more efficient in individuals carrying the Fc $\gamma \mathrm{RIIa}-\mathrm{H} / \mathrm{H}$ genotype $(59,60)$. This suggests that FcyRIIa polymorphism may also indirectly influence CD4+ T cell function, and subsequent disease progression through its effect on immune complex internalization by monocytes and dendritic cells leading to their activation $(59,60)$. 
TABLE 1 | Studies of FCyR polymorphisms and infection outcomes.

\begin{tabular}{|c|c|c|c|c|c|}
\hline $\begin{array}{l}\text { Population } \\
\text { from }\end{array}$ & $\begin{array}{l}\text { Type of } \\
\text { study }\end{array}$ & Sample size & Receptor & Main outcome & Reference \\
\hline Kenya & In vitro & $\begin{array}{l}250 \text { female sex } \\
\text { workers }\end{array}$ & 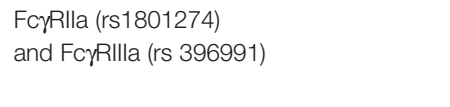 & $\begin{array}{l}\text { No association with HIV-1 disease progression, viral set point } \\
\text { or CD4 decline. Examined with individuals with FcyRlla 131- } \\
\mathrm{H} / \mathrm{R} \text { or } \mathrm{H} / \mathrm{H} \text { and FcyRIlla 176-FN, F/F or VN genotypes. }\end{array}$ & $(46)$ \\
\hline $\begin{array}{l}\text { USA, } \\
\text { African } \\
\text { Americans }\end{array}$ & Genotyping & $\begin{array}{l}172 \text { HIV-1 } \\
\text { progressors and } \\
\text { natural viral } \\
\text { controllers }\end{array}$ & $\begin{array}{l}\text { FcyRlla (rs1801274) and FcyRIlla and (rs } \\
\text { 396991) }\end{array}$ & $\begin{array}{l}\text { Fc } \gamma R \text { RIIIa-V176 but not FcyRlla-H131 was significantly } \\
\text { associated with HIV-1 disease progression. }\end{array}$ & $(47)$ \\
\hline Kenyan & Genotyping & $\begin{array}{l}379 \text { mother-infant } \\
\text { pairs }\end{array}$ & 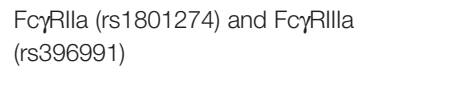 & 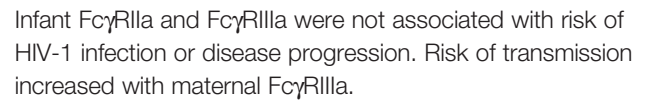 & $(48)$ \\
\hline India & $\begin{array}{l}\text { Genotyping } \\
\text { and in vitro }\end{array}$ & $\begin{array}{l}63 \text { HIV-1 infected } \\
\text { individuals and } 76 \\
\text { HIV-1 controls }\end{array}$ & FcyRIIla (rs396991 and rs396716) & $\begin{array}{l}\text { FcyRIIIa-V176F (rs396991) and Y158H (rs396716) genotypes } \\
\text { significantly associated with higher HIV-1 specific ADCC } \\
\text { response. }\end{array}$ & $(49)$ \\
\hline USA & Genotyping & $\begin{array}{l}559 \text { HIV-1 infected } \\
\text { males }\end{array}$ & $\begin{array}{l}\text { FcyRlla (rs1801274) and FcyRllla } \\
\text { (rs396991) }\end{array}$ & $\begin{array}{l}\text { Association with risk of HIV-1 infection progression and } \\
\text { faster rate of CD4 decline for FcyRlla-131RR. FcyRIlla-V176F } \\
\text { alleles were associated with risk of Kaposi's sarcoma. }\end{array}$ & $(12)$ \\
\hline $\begin{array}{l}\text { Rwanda } \\
\text { and Zambia }\end{array}$ & $\begin{array}{l}\text { Genotyping } \\
\text { and in vitro }\end{array}$ & $\begin{array}{l}836 \text { HIV-1 infected } \\
\text { Heterosexual sero- } \\
\text { discordant couples }\end{array}$ & 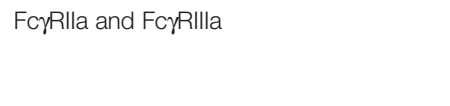 & $\begin{array}{l}\text { No clear FcyRlla-H131R and FcyRIIla-V176F association with } \\
\text { time to HIV-1 acquisition, viral load in early infection, or CD4+ } \\
\text { T-cell decline over time after infection. }\end{array}$ & $(50)$ \\
\hline Paris & In vitro & $\begin{array}{l}12 \text { HIV-1 infected } \\
\text { individuals }\end{array}$ & FcyRlla (CD32a) & A marker for HIV-1 reservoir. & $(51)$ \\
\hline Thailand & In vitro & $\begin{array}{l}125 \text { HIV-1 infected } \\
\text { individuals }\end{array}$ & FcyRllc (rs114945036) & $\begin{array}{l}\text { Associated with protection from HIV-1 infection in RV144 } \\
\text { vaccine recipients in individuals carrying the FCGR2C } \\
126 \mathrm{C}>\mathrm{T} \text { genotypes. }\end{array}$ & $(13)$ \\
\hline Spain & In vitro & $\begin{array}{l}23 \mathrm{HIV}-1 \text { infected } \\
\text { males }\end{array}$ & FcyRlla (CD32a) & A marker for T cell activation, but not for HIV-1 reservoir. & $(52)$ \\
\hline USA & In vitro & $\begin{array}{l}58 \mathrm{HIV}-1 \text { infected } \\
\text { males and females }\end{array}$ & 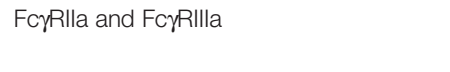 & $\begin{array}{l}\text { All genotypes were associated with enhanced FcrR signaling } \\
\text { in HIV-1 viremic controllers. }\end{array}$ & (53) \\
\hline South Africa & In vitro & $\begin{array}{l}193 \text { HIV-1 infected } \\
\text { and control } \\
\text { subjects }\end{array}$ & $\begin{array}{l}{ }^{*} \mathrm{~F} c \gamma R \| l \mathrm{l}(\mathrm{rs} 138747765, \mathrm{rs} 78603008, \\
\text { rs373013207 rs201984478) and FcyRIllb } \\
\text { (rs34322334, rs61803026, rs34085961) }\end{array}$ & $\begin{array}{l}\text { FCGR2C-TATA and FCGR3B-AGA haplotypes increased the } \\
\text { risk of HIV-1 acquisition in some HVTN } 505 \text { vaccinees but } \\
\text { not in others. }\end{array}$ & (54) \\
\hline Kenya & In vitro & $\begin{array}{l}448 \text { HIV }-1 \\
\text { seropositive } \\
\text { women and their } \\
\text { infants }\end{array}$ & $\begin{array}{l}\text { FcyRlla } \\
(\text { rs1801274) }\end{array}$ & $\begin{array}{l}\text { Infant } \mathrm{Fc} \gamma \mathrm{R} \text { lla- } \mathrm{H} 131 \mathrm{H} \text { genotype was associated with risk of } \\
\text { perinatal } \mathrm{HIV}-1 \text { transmission. }\end{array}$ & (35) \\
\hline Kenya & In vitro & $\begin{array}{l}903 \text { pregnant } \\
\text { women }\end{array}$ & $\begin{array}{l}\text { FcyRlla } \\
(\text { rs1801274) }\end{array}$ & $\begin{array}{l}\text { FcyRlla-131H/H genotype associated with high risk of } \\
\text { placental malaria in HIV-1 positive women compared to HIV } \\
\text { negative women. }\end{array}$ & (55) \\
\hline Europe & $\begin{array}{l}\text { Genetic } \\
\text { association } \\
\text { studies }\end{array}$ & $\begin{array}{l}7,247 \text { population } \\
\text { samples }\end{array}$ & 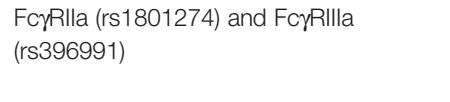 & No association of these polymorphisms in HIV-1 acquisition & $(56)$ \\
\hline USA & $\begin{array}{l}\text { In Vitro/In } \\
\text { vivo }\end{array}$ & 1725 male subjects & 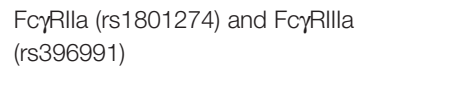 & $\begin{array}{l}\text { Homozygous FcyRIIla V176 allele individuals were more likely } \\
\text { to acquire HIV -1 among vaccinees. No association of } \\
\text { FcyRlla genotype and HIV-1 infection rate }\end{array}$ & (36) \\
\hline South India & In vitro & $\begin{array}{l}120 \text { Periodontitis } \\
\text { subjects and } \\
\text { controls }\end{array}$ & $\begin{array}{l}\text { FcyRIIlla } \\
\text { (rs396991) }\end{array}$ & $\begin{array}{l}\text { FcyRIIla-V176V genotype may be a risk factor for chronic } \\
\text { periodontitis }\end{array}$ & $(57)$ \\
\hline USA & In vitro & 250 male subjects & $\begin{array}{l}\text { FcyRIIla } \\
\text { (rs396991) }\end{array}$ & $\begin{array}{l}\text { FcyRIIla-V176F genotype significantly associated with the risk } \\
\text { of developing Kaposi's sarcoma during HIV-1 infection. }\end{array}$ & $(37)$ \\
\hline USA & In vitro & $\begin{array}{l}164 \text { HIV infected } \\
\text { cases and controls }\end{array}$ & $\begin{array}{l}\text { FcyRIlla } \\
\text { (rs396991) }\end{array}$ & $\begin{array}{l}\text { An association between the FcyRIIla-176V allele and risk for } \\
\text { HIV-1 associated cryptococcal disease. }\end{array}$ & (38) \\
\hline
\end{tabular}

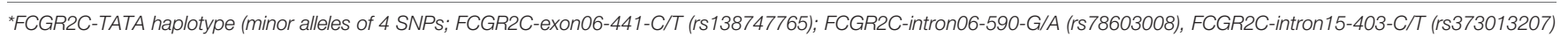
and FCGR2C-intron15-433-G/A (rs201984478).

FCGR3B-AGA haplotype (minor alleles of 3 SNPs; FCGR3B-5'utr44-T/A (rs34322334), FCGR3B-5'utr99-C/G (rs61803026), and FCGR3B-5'utr222-G/A (rs34085961).

Surprisingly, the $131 \mathrm{R} / \mathrm{R}$ genotype was found to be associated with decreased AIDS-induced pneumonias compared to the $131 \mathrm{H} / \mathrm{H}$ genotype in the MACS cohort. Given that FcyRIIa also binds to C-reactive proteins (61), it is possible that during bacterial infections, carriers of the 131R/R genotype may have higher levels of CRP to opsonize IgG2-coated microbes and activate the complement receptors to clear infection (62).
A recent study showed that HIV-1 patients with homozygous 176V for the Fc $\gamma$ RIIIa-V176F (rs396991) polymorphisms and/or Y158H (rs396716) genotypes have higher HIV-1 specific ADCC response (49). It was hypothesized that the V176F polymorphism improves the binding capacity between the $\mathrm{Fc}$ receptor and anti-HIV-1 antibody, indicating that the FcyRIIIa receptor expressed on NK cells induced strong ADCC response 
for viral clearance $(63,64)$. When Geraghty et al. examined the role of Fc $\gamma$ RIIa-(rs1801274) and Fc $\gamma R I I I a-(r s 396991)$ polymorphisms in $6300 \mathrm{HIV}+$ adults with European ancestry from a previous GWAS (65), they did not find any association between these polymorphisms and HIV acquisition (56). Furthermore, in the largest study of its kind in Africa, Connolly and colleagues also found no association between

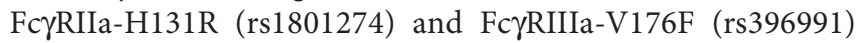
variants and $\mathrm{HIV}$ infection or $\mathrm{CD} 4+\mathrm{T}$-cell decline in two cohorts in Rwanda and Zambia (50).

Accumulating evidence suggest that Fc $\gamma \mathrm{R}$ polymorphisms may play a key role in HIV-1 acquisition when vaccines are involved $(13,36,54,66-68)$. In the recombinant HIV-1 glycoprotein (gp120) Vax004 vaccine trial in the USA, those homozygous for the FcyRIIIa V176 allele in the lowest behavioral risk group were more likely to acquire HIV compared to individuals carrying the FcyRIIIa $176 \mathrm{~F}$ or V176F genotypes in the same behavioral risk group (36). However, in that same study, no FcyRIIa-H131R (rs1801274) genotype was associated with increased risk of HIV among vaccine and placebo recipients. Furthermore, in the RV144 trial in Thailand, a SNP in FCGR2C (126C>T, rs114945036) was associated with vaccine efficacy. The study found an 11 to $15 \%$ efficacy in CC subjects compared to 64 to $91 \%$ in CT/TT subjects with the HIV subtype CRF01_AE 169K HIV-1 (13). On the contrary, in the HVTN 505 vaccine trial, the effect modification of this SNP with respect to vaccine efficacy was not significant. However, other four SNPs; (FCGR2C-exon06-441-C/T, rs138747765, FCGR2C-intron06590-G/A, rs78603008, FCGR2C-intron15-403-C/T, rs373013207 and FCGR2C-intron15-433-G/A, rs201984478), were associated with increased risk of acquiring HIV in those vaccinated compared to the placebo group (54). These studies provide evidence that FcyR polymorphisms impact HIV-1 infection outcomes differently in vaccine recipients. The affinity of different IgG isotypes and the expression pattern of these Fc $\gamma R$ on effector cells could account for these differences. For instance, when neutralizing antibodies induced during HIV1 vaccination $(69,70)$ are ineffective against the virus, the antibody-virus complexes formed could lead to antibody dependent enhancement, resulting in virus spread among cells expressing these receptors (71-73).

It is also possible that vaccine types and their modes of delivery could trigger different $\mathrm{Fc} \gamma \mathrm{R}$ responses. For instance, the RV144 vaccine consists of recombinant canarypox vector containing HIV antigens and recombinant gp120 administered in a prime-boosted regimen, while the HVTN 505 vaccine was made of a recombinant adenovirus serotype 5 vector boost (DNA/rAd5). The HVTN 505 vaccination increased the risk of HIV-1 acquisition. In addition, there were additional Fc $\gamma \mathrm{R}$ SNPs in HVTN 505 (FCGR3B SNPs) that modified vaccine effect in relation to HIV-1 acquisition compared to the RV144 vaccine recipients who had no such SNP associations (54). Furthermore, some minor SNPs identified on FCGR2C intron 6 were found to be in high linkage disequilibrium with others. This SNP may have selectively modulated the expression of Fc $\gamma \mathrm{R}$ effector functions differently in the two vaccines mentioned above (54). The FCGR2C polymorphisms, which was found in Thai RV144 vaccinees (13), was absent in Africans. This has implications for determining vaccine responses in other populations, if these FCGR2C polymorphisms are used as a proxy for Fc $\gamma$ RIIc expression (45). Hence, it is possible that ethnic group, vaccine types and methods for delivering the vaccines may all trigger differences in $\mathrm{Fc} \gamma \mathrm{R}$ dependent responses.

It has been proposed that during vaccination, Fc $\gamma R$ polymorphism influence HIV-1 acquisition through their effect on the innate immune response. During HIV-1 infection, plasmacytoid dendritic cells produce high levels of interferon, which restricts the replication of virus (74). However, when viral particles are opsonized, there is suppression of type I and III interferons that are produced via Fc $\gamma \mathrm{R}$-mediated mechanisms. This results in the lowering of the interferon levels required to block infection $(54,75)$.

$\mathrm{Fc} \gamma \mathrm{R}$ polymorphisms also determine the affinity to the Fc region of IgG and alter its functionality after vaccination. For instance, in the HVTN 505 vaccine trial, differences in Fc $\gamma$ RIIa binding and gp140-specific ADCP activity among the vaccine and control groups occurred in only one genotype of the Fc $\gamma$ RIIa and Fc $\gamma$ RIIb SNPs (54). This suggests that Fc $\gamma R$ polymorphisms influenced the variation observed in the Fc region of the IgG induced after HVTN 505 vaccination (54). Also, studies have shown variation in Fc glycosylation of HIV-specific antibodies in HIV-1 infected patients and vaccine recipients, an indication that it regulates antibody and Fc $\gamma \mathrm{R}$ interaction $(76,77)$. Although these findings suggest possible mechanisms associated with increased risk of HIV-1infection in HVTN-505 vaccine among individuals carrying certain FcyRIIc genotypes, the same effect could not be established among recipients of the RV144 vaccine. These studies underscore the need to consider FcyR polymorphisms in HIV-1 vaccine trials, since they regulate vaccine-induced immunity, which impacts on HIV infection outcomes $(36,54)$.

\section{FC $\gamma R$ Polymorphisms, HIV Disease Progression and ART Outcomes}

Several studies have evaluated $\mathrm{Fc} \gamma \mathrm{R}$ polymorphism and infection progression in European populations, however, studies on $\mathrm{Fc} \gamma \mathrm{R}$ polymorphisms and ART outcomes are lacking. Fc $\gamma \mathrm{R}$ polymorphisms have been shown to affect the viral reservoir size in acute HIV-1 patients who were put on early $\operatorname{ART}(78,79)$.

In a meta-analysis of several genome-wide association studies comprising 7,266 patients in the International Collaboration for the Genomics of HIV (ICGH), no association between Fc $\gamma$ RIIa (rs1801274) and FcyRIIIa (rs396991) polymorphisms and viral set point was found [reviewed in (56)]. Similarly, in a subanalysis of 467 long-term non-progressors and 517 rapid progressors, there was no association between Fc $\gamma$ RIIa polymorphisms and HIV-1 disease progression. Finally, in the same meta-analysis, Fc $\gamma$ RIIIa polymorphisms were not associated with HIV-1 disease progression in the Swiss HIV Cohort Study (SHCS) (56). Although another study found homozygous FcyRIIIa-176V/V to be highly prevalent in HIV progressors on ART compared to untreated natural viral 
suppressors, they could not conclude on this polymorphism's association with viral set point (47). This is probably because the use of ART for HIV progressors in this study influenced their viral load, hence analysis with this polymorphism with respect to viral load could not be substantiated. Similarly, a study conducted in 253 Kenyan women to evaluate the impact of Fc $\gamma$ RIIa-131H/R genotypes and FcrRIIIa-176F/V polymorphisms on HIV-1 disease progression could not find an association between these polymorphisms with viral load set point, decrease in CD4 count or increase in viral load (46).

The studies above agree that Fc $\gamma$ RIIa and Fc $\gamma$ RIIIa genotypes have no effect on viral load set point, but the results on disease progression differ. The divergent results on disease progression could be due to sample size, different study populations (i.e., men versus women), clinical definitions and the rigorousness of statistical methods employed. Additionally, the differences in these genotypic profiles among the different study populations and association with infection progression may be due to other factors such as viral type, host immunity and genetics. Future studies investigating the role of FcyRs in HIV-1 disease progression should comprehensively address potential population substructure, and longitudinally, pre-existing neutralizing antibodies and genetic variability in the virus to ascertain how these variables influence the outcome. Though haplotype analyses within and between the Fc $\gamma \mathrm{R}$ genes may offer crucial information on why these differences exist, such studies have been few $(11,80)$. Differences within the FCGR locus for different populations have been established (81-85). For instance, Fc $\gamma$ RIIIa-176V was found to be underrepresented in Kenyan population $(23.7 \%)$ compared to Europeans and Dutch Caucasians, whiles Fc $\gamma$ RIIa-131H and Fc $\gamma$ RIIc were highly prevalent in Asians compared with Caucasians (45). In addition, the distribution of Fc $\gamma$ RIIIb-HNA1a/HNA1b allotypes were different among different populations, however, the FcyRIIIb-HNA1a and Fc $\gamma$ RIIb- 232T variants were highly prevalent in black South Africans compared with Caucasians (45). Different effector functions have been observed in these populations with respect to enhanced cell activation and neutrophil-mediated phagocytosis as a result of these polymorphisms (45). Furthermore, gene copy number

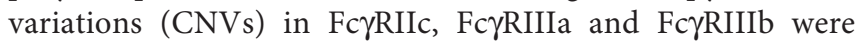
shown to play a key role in association with HIV-1 infection and ART outcomes $(45,80)$.

Most of the studies on Fc $\gamma \mathrm{R}$ polymorphisms were conducted in Europe, USA, Asia and a few in South Africa. Data on the impact of Fc $\gamma \mathrm{R}$ polymorphisms and $\mathrm{CNV}$ on HIV-1 infection are limited in most African populations (12, 13, 45). One study examining the effect of Fc $\gamma$ RIIc, Fc $\gamma$ RIIIa and Fc $\gamma$ RIIIb CNV in Ethiopian and Tanzanian cohorts found no effect on immune reconstitution post ART (80). Thus, supporting the limited role of poorly neutralizing or non-neutralizing antibodies in HIV-1 control $(67,86)$. This was contrary to the hypotheses that different Fc $\gamma$ Rs play a key role in mediating a balance between activating and inhibitory functions, IgG binding affinity to receptors and antibody mediated responses in HIV-1 infection progression. These findings in the Tanzanian and Ethiopian cohorts could also be due to epistatic interactions between these $\mathrm{Fc} \gamma \mathrm{R}$ variants and IgG affinity, that will mediate HIV pathogenesis as evidenced in KIR/HLA variants (87).

Importantly, data is lacking on Fc $\gamma \mathrm{R}$ influence on HIV-1 disease progression and ART responses in African populations, though the continent bears the brunt of the epidemic. Therefore, large studies conducted in populations with African ancestry are needed. This will provide increased power to detect population specific genetic variations in association with disease progression, when combined with data from European populations $(11,88)$.

\section{FC $\gamma R$ POLYMORPHISMS AND VIRAL RESERVOIR}

Though ART has been used successfully in the management of HIV-1 infection, replication-competent viruses persist as latent reservoirs after long term ART usage (89). Even HIV-1 elite controllers and long term non-progressors, harbor viral reservoirs $(9,10)$. The extent of viral clearance in HIV-1 infection, will be dependent on both an efficient HIV-1 specific immune response and a very low reservoir size (90). To achieve an HIV cure or remission, the viral reservoir must be eliminated or reduced to a minimum, since the size of the viral reservoir has been shown to be a marker for disease progression and clinical outcomes $(91,92)$. Therefore, reduction of the reservoir can be used as a criterion for ART interruption in HIV-1 cure studies (92). The impact of Fc $\gamma$ Rs on ART outcomes needs further evaluation, since it has been hypothesized that some polymorphisms affect the viral reservoir size in patients with acute HIV-1 infection initiated on early ART $(78,79)$. However, such studies analyzing Fc $\gamma$ Rs polymorphisms and HIV reservoir size are currently lacking.

There is now increased focus on identifying markers for these latent reservoirs to help in the HIV-1 cure efforts. Receptors expressed on infected cells such as CD30 and CD32 (FcyRIIa) and some immune checkpoint inhibiting molecules on the surfaces of infected cells have been identified as potential markers for latently infected cells $(51,52,93)$. Recently, CD32a (Fc $\gamma$ RIIa) was identified as a marker of latently infected CD4 T cells. In this study CD4+ T cells expressing CD32a+ molecules were observed to be highly enriched in HIV-1 DNA and contained replication competent proviruses compared to the CD32a- CD4+ T cells (51). However, these findings were not replicated in other studies. Some investigators reported lower enrichment for HIV-1 DNA in cells expressing CD32 in certain individuals $(52,93)$. Others could not verify that CD32a is expressed on latent reservoirs, nor enriched in CD4+ T cells carrying viral DNA (94-96). A study that used 10 chronic HIV-1 patients on ART also observed no enrichment for HIV-1 DNA in CD32+ CD4 T cells (95). Some investigators proposed that the $\mathrm{CD} 32+$ cells may have been derived from adherent non- $\mathrm{T}$ cells and other cell conjugates ( $\mathrm{T}-\mathrm{B}$ cell conjugates) expressing this marker (95). Another study proposed that CD32 (Fc $\gamma \mathrm{RII})$ is not a specific biomarker for most CD4 T cell populations because they found a greater number of HIV-1 latent reservoirs occurred in CD3+CD4+ CD32- $\mathrm{T}$ cells using a quantitative viral outgrowth assay (qVOA) (97). 
Some studies have suggested that the inconsistencies in these findings could be attributed to cell sorting techniques that was not able to isolate pure CD4 $\mathrm{T}$ cells that express only CD32+ marker, but rather T-B cell doublets $(96,98)$. In addition, it has been shown that there is a higher proportion of antigen presenting cells (APC) expressing CD32+ cells than what is expressed on CD4+ T cells. Therefore, high number of residual non- $\mathrm{T}$ cells found in sorted CD32+ cell population, can bias these findings $(93,95,99,100)$. The cell sorting challenges seem to have been overcome by Darcis and colleagues using an improved isolation and purification technique. They performed two rounds of CD4+ $\mathrm{T}$ cell negative selection by magnetic cell sorting before CD32 isolation. Using this method, they observed an increased HIV-1 DNA enrichment in the CD32+ CD4+ T cells (100) as seen in the original study by Descours et al.

Further studies that replicate the sequential cell sorting techniques used by Darcis and colleagues are needed (99) to firmly establish Fc $\gamma$ RIIa as bona fide marker of latently infected CD4+ cells. After that, several questions still remain: Is FcyRIIa just a marker of these latently infected cells or does it have functional consequences on the size or reactivation capacity of the reservoir? Do polymorphisms and CNVs in FcyRIIa and other $\mathrm{Fc}$ receptors determine the size of the reservoir in individuals treated with ART? Does it matter if the persons are treated early during HIV infection? What about the tissue reservoirs, do they also express FcyRIIa and if so, do polymorphisms and $\mathrm{CNV}$ matter in that context? Investigators have started to address some of these important questions. Some have hypothesized that the differences in reservoir size in people who started early on ART may be due to polymorphisms in Fc $\gamma$ RIIa $(78,101)$, since there has been previous association of this gene with HIV-1 disease pathogenesis. However, this hypothesis needs to be tested. Notably, these reservoirs are diverse in nature, occurring in various infected cells and tissues, and thus may enhance the long-term persistence of replication competent viruses $(99,102,103)$. Also, since there is some evidence that CD32 (FcyRIIa) marks transcriptionally active HIV-1 infected cells, they could be used to identify persistent HIV-1 infected CD4 T cells that may contribute to viral persistence during antiretroviral treatments $(104,105)$. The co-expression of CD32a (Fc $\gamma$ RIIa) with other markers such as PD-1 in lymph node CD4+ T cells (105) as well as CD32a occurring with CD30 in CD4+ T cell tissues (104), shows these reservoirs are heterogenous in nature.

In a previous study of HIV controllers and non-controllers, epistatic interactions between of genes (GM on chromosome 14) encoding variability in the Fc portion of IgG and FcyR genes (on chromosome 1) were reported to influence the control of HIV-1 viral replication in Caucasian Americans (106). Homozygous Fc $\gamma$ RIIa-H individuals who were also GM21 non carriers (homozygous GM5) were more likely to be HIV controllers than GM21 carriers. A similar interaction between GM determinants and FcyRIIIa alleles on HIV control albeit mush weaker compared to that with Fc $\gamma$ RIIa. Interestingly, these epistatic interactions between Fc $\gamma \mathrm{R}$ and GM genes were not observed in the African-American population in the same study highlighting population specific effects of these genes in HIV control (106). In a more recent study, the Fc $\gamma$ RIIa AA genotype (rs10800309) was found to increase FcyRIIa expression on myeloid cells and was associated with HIV-1 control independent of HLA-B57 and HLA-B27 (107), which are well established markers involved in controlling viral load and longterm non-progression of HIV infection $(108,109)$. Taken together, these studies underscore the importance of studies assessing the role of Fc $\gamma \mathrm{R}$ polymorphisms in HIV to be designed to adequately address inter-ethnic differences in these genes and the potential impact of genetic variability affecting not only the receptor-ligand interphase but also receptor expression levels.

\section{FC $\gamma R S$, BROADLY NEUTRALIZING ANTIBODIES AND HIV-1 REMISSION ATTEMPTS}

Investigators are exploring different approaches to achieve a remission or cure for HIV (Table 2). First, there are strategies that seek to boost the host immune system using vaccines that produce broadly neutralizing antibodies (bNAbs) to suppress the virus, or chimeric antigen receptors to engage and destroy the latently infected cells. Second, genetic methods like the CRISPR/ Cas9 gene editing technology to excise or mutate the integrated virus or render patients resistant to HIV by taking their CD4+ T cells, mutating essential receptors such as CCR5 and reinfusing them back into the patient (126-128). Third, and probably the most studied of the HIV cure methods is the shock and kill approach which seeks to use compounds to reactivate the latent virus with the hope that infected $\mathrm{CD}+\mathrm{T}$ cells will die by viral cytopathic effects or immune clearance (129-132). The use of bNAbs, chimeric antigen receptors, and the 'kill' part of the shock and kill approach may all involve the engagement of Fc gamma receptors. Fc $\gamma \mathrm{R}$ binding seems to be a key requirement for bNAbs to efficiently protect from infection, viral suppression, and clearance. Studies conducted in animal models observed a decrease in broadly neutralizing antibody activity from simianhuman immunodeficiency virus (SHIV-1) challenge when the Fc $\gamma \mathrm{R}$ and complement activities were disabled (118). Similarly, bNAbs enhanced binding capacity for activating Fc $\gamma$ Rs Fc $\gamma$ RIIa and FcyRIIIa, which were demonstrated to be protective in humanized murine models (133).

In contrast, though both the WT PGT121 and LALA PGT121 bNAbs administered to macaques, conferred protection against cell associated SHIV SF162P3 challenge, when tested in vitro, the Fc-dependent function was greatly reduced. Although, these two bNAbs have been shown to be associated with reduced plasma viremia both in macaques and humanized mice models (133, 134), indication that the protection conferred by PGT121, may not be dependent on Fc-mediated NK cells responses (120, 135, 136). It has been suggested that the mechanism by which these bNAbs neutralize both cell-free virus and cell-associated virus and confer protection could be through the fragment antigenbinding (Fab) region, as well as epitope specificity of these antibodies (120). Additional studies on other bNAbs and other modified bNAbs in different animal models are needed to validate these results (120). These findings have emphasized 
TABLE 2 | Vaccine and bNAb studies.

\begin{tabular}{|c|c|c|c|c|c|}
\hline Research Type & $\begin{array}{l}\text { Type } \\
\text { of } \\
\text { study }\end{array}$ & $\begin{array}{l}\text { Performed } \\
\text { in }\end{array}$ & Mechanism of Action & Main Outcome & Reference(s) \\
\hline $\begin{array}{l}\text { Phase } 1 \mathrm{HIV}-1 \\
\text { Clinical Trial }\end{array}$ & $\begin{array}{l}\text { In } \\
\text { vivo/ } \\
\text { In } \\
\text { vitro }\end{array}$ & $\begin{array}{l}\text { USA } \\
\text { volunteers }\end{array}$ & $\begin{array}{l}\text { Targets CD4-binding site of the HIV-1 envelope } \\
\text { glycoprotein. }\end{array}$ & $\begin{array}{l}\text { Fc modified -VRC01LS (bnMAbs) vaccine was well } \\
\text { tolerated, with 4-fold increase in half-life, compared to } \\
\text { wild type. }\end{array}$ & (66) \\
\hline RV144 ALVAC-HIV & $\begin{array}{l}\text { In } \\
\text { vivo/ } \\
\text { In } \\
\text { vitro }\end{array}$ & $\begin{array}{l}\text { USA } \\
\text { volunteers }\end{array}$ & $\begin{array}{l}\text { RV144 HIV-1 vaccine protection partially due to } \\
\text { ADCC-mediating antibodies. }\end{array}$ & $\begin{array}{l}\text { Antibody binding to envelope V1V2 was associated } \\
\text { with HIV-1 infection risk. }\end{array}$ & $(67,110-116)$ \\
\hline $\begin{array}{l}\text { Phase III RV144 } \\
\text { ALVAC/AIDSVAX } \\
\text { clinical trial }\end{array}$ & $\begin{array}{l}\text { In } \\
\text { vivo/ } \\
\text { In } \\
\text { vitro }\end{array}$ & $\begin{array}{l}\text { Thai } \\
\text { volunteers }\end{array}$ & $\begin{array}{l}\text { Vaccine-induced FcR-mediated antibody function } \\
\text { was associated with reduced risk of HIV-1 infection }\end{array}$ & $\begin{array}{l}\text { FCGR2C tag SNP (rs114945036) was associated } \\
\text { with VE against HIV-1 subtype CRF01_AE. Individuals } \\
\text { with CC SNPs had } 15 \% \text { vaccine efficacy compared } \\
91 \% \text { of those carrying CT or } T \text {. }\end{array}$ & (13) \\
\hline bNAbs & $\begin{array}{l}\text { In } \\
\text { vitro }\end{array}$ & Cell lines & $\begin{array}{l}\text { Impair clustering and fusion of infected and target } \\
\text { cells, blocked the transfer of virions to uninfected T } \\
\text { cells }\end{array}$ & $\begin{array}{l}\text { VRC01, NIH45-46 bNAbs prevented HIV-1 cell-to-cell } \\
\text { transmission }\end{array}$ & $(70)$ \\
\hline bNAbs & $\begin{array}{l}\text { In } \\
\text { vivo/ } \\
\text { In } \\
\text { vitro }\end{array}$ & $\begin{array}{l}\text { humanized } \\
\text { mouse } \\
\text { models }\end{array}$ & $\begin{array}{l}\text { Fc domain-engineered bNAb variants 3BNC117 } \\
\text { (GASDALIE) and mouse IgG1 variant (D265A) }\end{array}$ & $\begin{array}{l}\text { Fc domain engineering of anti-HIV-1 bNAbs } \\
\text { enhanced interaction with activating FCGRs in an in- } \\
\text { vivo model of HIV-1 entry. }\end{array}$ & $(117)$ \\
\hline bNAbs & $\begin{array}{l}\text { In } \\
\text { vivo/ } \\
\text { In } \\
\text { vitro }\end{array}$ & $\begin{array}{l}\text { Rhesus } \\
\text { macaque } \\
\text { model }\end{array}$ & $\begin{array}{l}\text { KA (K322A) variant blocks complement activity but } \\
\text { active in FCGR binding. The L234A, L235A (LALA) } \\
\text { variant is defective of both complement and FCGR } \\
\text { binding }\end{array}$ & $\begin{array}{l}\text { Decreased protection of bNAbs against SHIV } \\
\text { challenge when Fc receptor and complement-binding } \\
\text { activities were engineered out of the antibody. }\end{array}$ & $(118,119)$ \\
\hline bNAbs & $\begin{array}{l}\text { In } \\
\text { vivo/ } \\
\text { In } \\
\text { vitro }\end{array}$ & $\begin{array}{l}\text { Macaque } \\
\text { model }\end{array}$ & $\begin{array}{l}\text { WT bNAbs PGT121 and a LALA mutant of } \\
\text { PGT121 (impaired Fc-dependent function) was } \\
\text { experimented for ability to protect pigtail macaques }\end{array}$ & $\begin{array}{l}\text { Potent neutralizing capacity of PGT121 renders the } \\
\text { Fc-dependent functions of the Ab are less effective }\end{array}$ & $(120)$ \\
\hline mAbs & $\begin{array}{l}\text { In } \\
\text { vitro }\end{array}$ & $\begin{array}{l}\text { Swiss } \\
\text { volunteers }\end{array}$ & $\begin{array}{l}\text { use of neutralizing monoclonal antibodies, gp41 } \\
\text { and mAb VRC01 in blocking HIV-1 infectivity }\end{array}$ & $\begin{array}{l}\text { CD4bs mAbs blocked free virus transmission but } \\
\text { allowed HIV-1 to spread among cell-cell contacts. }\end{array}$ & $(121)$ \\
\hline Antibodies & $\begin{array}{l}\text { In } \\
\text { vitro }\end{array}$ & $\begin{array}{l}\text { Australian } \\
\text { volunteers }\end{array}$ & $\begin{array}{l}\text { ADCC to activate NK cells, either from HIV-1 } \\
\text { positive or healthy donors. }\end{array}$ & $\begin{array}{l}\text { NK cells from the HIV+ subjects induced ADCC } \\
\text { responses to either gp140 Env protein or HIV-1 } \\
\text { peptide pools }\end{array}$ & $(122)$ \\
\hline Vaccine trial & $\begin{array}{l}\text { In } \\
\text { Vitro/ } \\
\text { In } \\
\text { Vivo }\end{array}$ & Americans & $\begin{array}{l}\text { Infected immune complexes easily bind, enter, and } \\
\text { infect susceptible FcyRIIla-176VN genotypes to } \\
\text { establish infection }\end{array}$ & $\begin{array}{l}\text { Homozygous FcyRIIla V176 allele individuals were } \\
\text { more likely to acquire HIV-1 among gp120 vaccinees. }\end{array}$ & (36) \\
\hline $\begin{array}{l}\text { Vectored } \\
\text { Immunoprophylaxis }\end{array}$ & $\begin{array}{l}\text { in } \\
\text { Vitro }\end{array}$ & $\begin{array}{l}\text { Humanized } \\
\text { mouse } \\
\text { models }\end{array}$ & $\begin{array}{l}\text { Use of vectored monoprophylaxis (VIP), a } \\
\text { specialized adeno-associated virus vector that } \\
\text { produces full-length antibody and induces lifelong } \\
\text { expression of these monoclonal antibodies. }\end{array}$ & $\begin{array}{l}\text { Humanized mice were fully protected from HIV-1, } \\
\text { when challenged intravenously with very high doses } \\
\text { of replication-competent virus }\end{array}$ & (123) \\
\hline $\begin{array}{l}\text { HIV-1 Gag-Pol } \\
\text { vaccine }\end{array}$ & $\begin{array}{l}\text { In } \\
\text { Vitro }\end{array}$ & Australia & $\begin{array}{l}\text { Use of recombinant fowl pox virus inserted with HIV } \\
\text { Gag-Pol genes and interferon gamma to control } \\
\text { HIV-1 after ART is ceased. }\end{array}$ & $\begin{array}{l}\text { There was lower replication of HIV-1 in patients with } \\
\text { IgG2 anti-p24 and carriers of FcyRlla-131 R/H } \\
\text { polymorphisms }\end{array}$ & $(68,124,125)$ \\
\hline
\end{tabular}

bNAb, broadly neutralizing antibodies; mAb, monoclonal antibodies.

the differences in the formulation of bNAbs, and how it affects their function in HIV control. Delineating what influences bNAb function either more through an Fc-mediated mechanism or otherwise would be very important in HIV cure research aimed at using bNAbs as immune-therapeutic tool in effective control and management of HIV.

During HIV-1 infections, broadly neutralizing antibodies (bNAbs) coordinate with Fc receptors to activate effector cells to clear the virus through mechanisms such as $\operatorname{ADCC}(21,67$, 122). In addition, there is evidence that neutralizing antibodies block cell-free virus through a mechanism that prevents cell-cell transmission. For instance, certain classes of CD4 binding site inhibitors (CD4b) such as mAb VRC01 only block free virus but has low activity during cell to cell transmission (121). Other
mAbs such as membrane-proximal external region (MPER), CD4bs and anti-coreceptor agents are involved in blocking free virus transmission $(137,138)$. Subsequent studies have shown that mAb VRC01 may engage Fc $\gamma$ Rs and prevent cell to cell HIV1 transmission and also reduce the half-lives of infected cells and free virions $(70,121)$. While a potent HIV-1 vaccine must block cell free virus and cell-cell virus transmission (121), using two or more bNAbs that bind different epitopes in combination could enhance efficacy and offer broader protection against HIV-1 infections. This was demonstrated when the combination of CD4bs and VRC07 resulted in the neutralization of about $98 \%$ viruses in one study (139). This notwithstanding, the role of antibodies in cell-cell HIV inhibition is divergent, since these findings were based on experiments conducted with several viral 
strains and antibodies, different donor and target cell types, as well as various HIV-1 transmission models (140). Hence some studies have reported similar HIV-1 inhibition for cell-free virus compared to cell-to-cell transmission (141-143), while others observed a decreased antibody effect in cell-to-cell transmission compared to cell free virus inhibition $(70,121,144)$. These controversies appear to have been resolved in comparative studies that obtained similar results when experimental designs were normalized with respect to target cells used, and antibody inhibition activities (141-143, 145). Thus, normalization of these factors must be done in terms of the type and quantity of virus and cell types using standardized assays to establish the role of these antibodies in cell free or cell-to-cell HIV transmission (140).

Fc $\gamma \mathrm{R}$ differences could also affect the efficacy of bNAbs as HIV-1 prevention agents. In animal studies, bNAbs confer protective immunity against HIV-1 or SHIV-1 challenge in humanized mouse models (Hessell et al., 2007, Balazs et al., 2012, Lu et al., 2016). Recently, Simone and colleagues observed that among a cohort of 23 individuals, 13 developed broadly neutralizing antibodies to HIV-1, which was significantly associated with antibody binding to FcyRIIa. These antibodies were associated with higher Fc polyfunctionality early in the course of infection (146). Furthermore, FcyRIIIa-V176F (rs396991) and FcyRIIIa-Y158H (rs396716) polymorphism are associated with enhanced ADCC in HIV-1 patients (49), giving the indication that the expression of FcyRIIIa receptor on NK cells led to the induction of strong ADCC response for viral clearance $(63,64)$. These studies suggest that bNAbs have potential as therapeutic or prophylactic treatment in humans. It is becoming clearer that if bNAbs are to become successful in eliminating the reservoir, Fc $\gamma \mathrm{R}$-mediated actions will play a pivotal role. It is therefore imperative to determine at this early stage if polymorphisms and CNVs affect how bNAbs can suppress or eliminate HIV-1 in different populations. This is especially crucial since inter-ethnic variations have been reported for polymorphisms in Fc $\gamma$ RIIa that influences its affinity for IgG binding $(45,147,148)$.

\section{PERSPECTIVES AND CONCLUSION}

Although several studies have evaluated the impact of Fc $\gamma \mathrm{R}$ polymorphisms on HIV progression, they do not appear to play a major role in viral load set point or natural control of

\section{REFERENCES}

1. UNAIDS. Global HIV \& AIDS Starictics -2019 Fact Sheet (2019). Available at: https://www.unaids.org/en/resources/fact-sheet.

2. Okulicz JF, Marconi VC, Landrum ML, Wegner S, Weintrob A, Ganesan A, et al. Clinical Outcomes of Elite Controllers, Viremic Controllers, and LongTerm Nonprogressors in the US Department of Defense HIV Natural History Study. J Infect Dis (2009) 200(11):1714-23. doi: 10.1086/646609

3. Grabar S, Selinger-Leneman H, Abgrall S, Pialoux G, Weiss L, Costagliola D. Prevalence and Comparative Characteristics of Long-Term Nonprogressors the virus. However, when it comes to HIV vaccine responses and remission attempts, Fc $\gamma \mathrm{R}$ polymorphisms and/or CNVs may play a variety of roles. First, if FcyRIIa (CD32) is confirmed as a true marker of the latent reservoir, it will raise many crucial questions as enumerated above. One such critical question is whether $\mathrm{Fc} \gamma \mathrm{R}$ polymorphisms determine the size of the viral reservoir. Second, the use of bNAbs either for reservoir elimination or long-term suppression may depend on engagement with FcyRs. It is important to determine if expression of different variants of Fc $\gamma$ Rs determine why these antibodies are successful in some persons but not others. Also, it will be significant to determine if Fc $\gamma$ Rs play a role in the development of resistance or immune tolerance to these antibodies. Third, Fc $\gamma$ Rs may need to be engaged in cure methods such as the 'shock and kill' approach, which seeks to reactivate the reservoir for clearance by the immune system. The 'kill' portion of this approach may involve interventions such as bNAbs or chimeric antigen receptors. The role of FcyRs in mediating successful killing of $\mathrm{T}$ cells that have been reactivated also need to be investigated especially after ART initiation as well as the synergistic effect between Fc $\gamma$ Rs and ART outcomes need to be evaluated. Finally, the responses to most HIV-1 vaccines are likely to be dependent on Fc $\gamma$ Rs as the few unsuccessful vaccine trials have shown. Therefore, investigations into Fc $\gamma \mathrm{R}$ variations in different populations offer an important area of inquiry in the HIV cure research era.

\section{AUTHOR CONTRIBUTIONS}

$\mathrm{HL}, \mathrm{BA}$, and GK designed the review and the concepts. EB assisted in the literature search and manuscript writing. All authors wrote and reviewed the manuscript. All authors contributed to the article and approved the submitted version.

\section{FUNDING}

This project is part of the EDCTP2 program supported by the European Union with grant numbers TMA2017SF-1955 senior fellowship to GK and TMA2018PF-2535 preparatory fellowship to HL. The funder had no role in the design, analysis, or publication of the study.

and HIV Controller Patients in the French Hospital Database on HIV. Aids (2009) 23(9):1163-9. doi: 10.1097/QAD.0b013e32832b44c8

4. Diop G, Hirtzig T, Do H, Coulonges C, Vasilescu A, Labib T, et al. Exhaustive Genotyping of the Interferon Alpha Receptor 1 (IFNAR1) Gene and Association of an IFNAR1 Protein Variant With AIDS Progression or Susceptibility to HIV-1 Infection in a French AIDS Cohort. Biomed Pharmacother (2006) 60(9):569-77. doi: 10.1016/j.biopha.2006.08.002

5. Casado C, Colombo S, Rauch A, Martínez R, Günthard HF, Garcia S, et al. Host and Viral Genetic Correlates of Clinical Definitions of HIV-1 Disease Progression. PLoS One (2010) 5(6). doi: 10.1371/journal.pone.0011079 
6. Fontaine J, Coutlée F, Tremblay C, Routy J-P, Poudrier JInfection MPH, et al. HIV Infection Affects Blood Myeloid Dendritic Cells After Successful Therapy and Despite Nonprogressing Clinical Disease. J Infect Dis (2009) 199(7):1007-18. doi: 10.1086/597278

7. Okulicz JF, Lambotte O. Epidemiology and Clinical Characteristics of Elite Controllers. Curr Opin HIV AIDS (2011) 6(3):163-8. doi: 10.1097/ COH.0b013e328344f35e

8. Tiemessen CT, Martinson N. Elite Controllers: Understanding Natural Suppressive Control of HIV-1 Infection. Continuing Med Education (2012) 30(8):282-5.

9. Graf EH, Mexas AM, Jianqing JY, Shaheen F, Liszewski MK, Di Mascio M, et al. Elite Suppressors Harbor Low Levels of Integrated HIV DNA and High Levels of 2-LTR Circular HIV DNA Compared to HIV+ Patients on and Off HAART. PLoS Pathogens (2011) 7(2). doi: 10.1371/ journal.ppat.1001300

10. Hocqueloux L, Prazuck T, Avettand-Fenoel V, Lafeuillade A, Cardon B, Viard J-P, et al. Long-Term Immunovirologic Control Following Antiretroviral Therapy Interruption in Patients Treated At the Time of Primary HIV-1 Infection. Aids (2010) 24(10):1598-601. doi: 10.1097/ QAD.0b013e32833b61ba

11. Lassaunière R, Musekiwa A, Gray GE, Kuhn L, Tiemessen CT. Perinatal HIV-1 Transmission: Fc Gamma Receptor Variability Associates With Maternal Infectiousness and Infant Susceptibility. Retrovirology (2016) 13 (1):40. doi: 10.1186/s12977-016-0272-y

12. Forthal DN, Landucci G, Bream J, Jacobson LP, Phan TB, Montoya B. Fcyriia Genotype Predicts Progression of HIV Infection. J Immunol (2007) 179 (11):7916-23. doi: 10.4049/jimmunol.179.11.7916

13. Li SS, Gilbert PB, Tomaras GD, Kijak G, Ferrari G, Thomas R, et al. FCGR2C Polymorphisms Associate With HIV-1 Vaccine Protection in RV144 Trial. J Clin Invest (2014) 124(9):3879-90. doi: 10.1172/JCI75539

14. Rosales C, Uribe-Querol E. Antibody-Fc Receptor Interactions in Antimicrobial Functions. Curr Immunol Rev (2013) 9(1):44-55. doi: 10.2174/1573395511309010006

15. Nimmerjahn F, Ravetch JV. Fcyrs in Health and Disease. Curr Topics Microbiol Immunol (2011) 350:105-25. doi: 10.1007/82_2010_86

16. Bournazos S, Ravetch JV. Anti-Retroviral Antibody Fcyr-Mediated Effector Functions. Immunol Rev (2017) 275(1):285-95. doi: 10.1111/imr.12482

17. Boesch AW, Brown EP, Ackerman ME. The Role of Fc Receptors in HIV Prevention and Therapy. Immunol Rev (2015) 268(1):296-310. doi: 10.1111/ imr.12339

18. Boross P, van de Poel K, Van de Winkel J, Leusen J. Fc Receptors. In: . Encyclopedia of Life Sciences (Els). Chichester: John Wiley \& Sons, Ltd (2008). p. 1-8. doi: 10.1002/9780470015902.a0000916.pub2

19. Maresco DL, Chang E, Theil KS, Francke U, Anderson CL. The Three Genes of the Human FCGR1 Gene Family Encoding Fc Gamma RI Flank the Centromere of Chromosome 1 At 1p12 and 1q21. Cytogen Cell Genet (1996) 73(3):157-63. doi: 10.1159/000134330

20. Hoffmeyer F, Witte K, Schmidt R. The High-Affinity Fcrri on PMN: Regulation of Expression and Signal Transduction. Immunology (1997) 92 (4):544-52. doi: 10.1046/j.1365-2567.1997.00381.x

21. Nimmerjahn F, Ravetch JV. Fc $\gamma$ Receptors as Regulators of Immune Responses. Nat Rev Immunol (2008) 8(1):34-47. doi: 10.1038/nri2206

22. Li X, Ptacek TS, Brown EE, Edberg JC. Fcgamma Receptors: Structure, Function and Role as Genetic Risk Factors in SLE. Genes Immun (2009) 10 (5):380-9. doi: 10.1038/gene.2009.35

23. Ernst LK, Metes D, Herberman RB, Morel PA. Allelic Polymorphisms in the Fcrriic Gene can Influence its Function on Normal Human Natural Killer Cells. J Mol Med (2002) 80(4):248-57. doi: 10.1007/s00109-001-0294-2

24. Breunis WB, van Mirre E, Bruin M, Geissler J, de Boer M, Peters M, et al. Copy Number Variation of the Activating FCGR2C Gene Predisposes to Idiopathic Thrombocytopenic Purpura. Blood (2008) 111(3):1029-38. doi: 10.1182/blood-2007-03-079913

25. Simmons D, Seed B. The Fc $\gamma$ Receptor of Natural Killer Cells is a Phospholipid-Linked Membrane Protein. Nature (1988) 333(6173):56870. doi: $10.1038 / 333568 \mathrm{a} 0$

26. Mayr L, Su B, Moog C. Role of Nonneutralizing Antibodies in Vaccines and/ or HIV Infected Individuals. Curr Opin HIV AIDS (2017) 12(3):209-15. doi: 10.1097/COH.0000000000000357
27. Chung AW, Alter G. Systems Serology: Profiling Vaccine Induced Humoral Immunity Against HIV. Retrovirology (2017) 14(1):57. doi: 10.1186/s12977017-0380-3

28. Forthal DN, Moog C. Fc Receptor-Mediated Antiviral Antibodies. Curr Opin HIV AIDS (2009) 4(5):388. doi: 10.1097/COH.0b013e32832f0a89

29. Li X, Gibson AW, Kimberly RP. Human FcR Polymorphism and Disease. In: M Daeron, F Nimmerjahn, editors. Fc Receptors. Cham: Springer International Publishing (2014). p. 275-302. doi: 10.1007/978-3-31907911-0_13

30. Endeman H, Cornips MCA, Grutters JC, van den Bosch JM, Ruven HJ, van Velzen-Blad H, et al. The Fc $\gamma$ Receptor IIA-R/R131 Genotype is Associated With Severe Sepsis in Community-Acquired Pneumonia. Clin Vaccine Immunol (2009) 16(7):1087-90. doi: 10.1128/CVI.00037-09

31. Platonov AE, Shipulin GA, Vershinina IV, Dankert J, van de Winkel JG, Kuijper EJ. Association of Human Fcyriia (CD32) Polymorphism With Susceptibility to and Severity of Meningococcal Disease. Clin Infect Dis (1998) 27(4):746-50. doi: 10.1086/514935

32. Jansen WT, Breukels MA, Snippe H, Sanders LA, Verheul AF, Rijkers GT. Fcy Receptor Polymorphisms Determine the Magnitude of In Vitro Phagocytosis of Streptococcus Pneumoniae Mediated by Pneumococcal Conjugate Sera. J Infect Dis (1999) 180(3):888-91. doi: 10.1086/314920

33. Yee AM, Phan HM, Zuniga R, Salmon JE, Musher DM. Association Between Fcrriia-R131 Allotype and Bacteremic Pneumococcal Pneumonia. Clin Infect Dis (2000) 30(1):25-8. doi: 10.1086/313588

34. Yuan FF, Tanner J, Chan P, Biffin S, Dyer W, Geczy A, et al. Influence of Fcyriia and MBL Polymorphisms on Severe Acute Respiratory Syndrome. Tissue Antigens (2005) 66(4):291-6. doi: 10.1111/j.13990039.2005.00476.x

35. Brouwer KC, Lal RB, Mirel LB, Yang C, Eijk AM, Ayisi J, et al. Polymorphism of Fc Receptor IIa for IgG in Infants is Associated With Susceptibility to Perinatal HIV-1 Infection. Aids (2004) 18(8):1187-94. doi: 10.1097/00002030-200405210-00012

36. Forthal DN, Gabriel EE, Wang A, Landucci G, Phan TB. Association of Fcy Receptor IIIa Genotype With the Rate of HIV Infection After gp120 Vaccination. Blood J Am Soc Hematol (2012) 120(14):2836-42. doi: 10.1182/blood-2012-05-431361

37. Lehrnbecher TL, Foster CB, Zhu S, Venzon D, Steinberg SM, Wyvill K, et al. Variant Genotypes of FcgammaRIIIA Influence the Development of Kaposi's Sarcoma in HIV-infected Men. Blood (2000) 95(7):2386-90. doi: 10.1182/blood.V95.7.2386.007k04_2386_2390

38. Rohatgi S, Gohil S, Kuniholm MH, Schultz H, Dufaud C, Armour KL, et al. Fc Gamma Receptor 3A Polymorphism and Risk for HIV-associated Cryptococcal Disease. MBio (2013) 4(5). doi: 10.1128/mBio.00573-13

39. Moi ML, Lim C-K, Takasaki T, Kurane I. Involvement of the Fcy Receptor IIA Cytoplasmic Domain in Antibody-Dependent Enhancement of Dengue Virus Infection. J Gen Virol (2010) 91(1):103-11. doi: 10.1099/ vir.0.014829-0

40. García G, González N, Pérez AB, Sierra B, Aguirre E, Rizo D, et al. LongTerm Persistence of Clinical Symptoms in Dengue-Infected Persons and its Association With Immunological Disorders. Int J Infect Dis (2011) 15(1): e38-43. doi: 10.1016/j.ijid.2010.09.008

41. García G, Sierra B, Pérez AB, Aguirre E, Rosado I, Gonzalez N, et al. Asymptomatic Dengue Infection in a Cuban Population Confirms the Protective Role of the RR Variant of the Fcyriia Polymorphism. Am J Trop Med Hygiene (2010) 82(6):1153-6. doi: 10.4269/ajtmh.2010.09-0353

42. Diamantopoulos PT, Kalotychou V, Polonyfi K, Sofotasiou M, Anastasopoulou A, Galanopoulos A, et al. Correlation of Fc- $\gamma$ RIIA Polymorphisms With Latent Epstein-Barr Virus Infection and Latent Membrane Protein 1 Expression in Patients With Low Grade B-cell Lymphomas. Leukemia Lymphoma (2013) 54(9):2030-4. doi: 10.3109/ 10428194.2012.762512

43. Zúñiga J, Buendía-Roldán I, Zhao Y, Jiménez L, Torres D, Romo J, et al. Genetic Variants Associated With Severe Pneumonia in A/H1N1 Influenza Infection. Eur Respir J (2012) 39(3):604-10. doi: 10.1183/ 09031936.00020611

44. Tarasenko T, Dean JA, Bolland S. FcgammaRIIB as a Modulator of Autoimmune Disease Susceptibility. Autoimmunity (2007) 40(6):409-17. doi: $10.1080 / 08916930701464665$ 
45. Lassauniere R, Tiemessen C. Variability At the FCGR Locus: Characterization in Black South Africans and Evidence for Ethnic Variation in and Out of Africa. Genes Immun (2016) 17(2):93. doi: 10.1038/gene.2015.60

46. Weis JF, McClelland RS, Jaoko W, Mandaliya KN, Overbaugh J, Graham SM. Fc Gamma Receptors IIa and IIIa Genetic Polymorphisms do Not Predict HIV-1 Disease Progression in Kenyan Women. AIDS Res Hum Retroviruses (2015) 31(3):288-92. doi: 10.1089/aid.2014.0209

47. Poonia B, Kijak GH, Pauza CD. High Affinity Allele for the Gene of FCGR3A is Risk Factor for HIV Infection and Progression. PLoS One (2010) 5(12). doi: 10.1371/journal.pone.0015562

48. Milligan C, Richardson BA, John-Stewart G, Nduati R, Overbaugh J. FCGR2A and FCGR3A Genotypes in Human Immunodeficiency Virus Mother-to-Child Transmission. Open Forum Infect Dis (2015) 2(4). doi: 10.1093/ofid/ofv149

49. Talathi SP, Shaikh NN, Pandey SS, Saxena VA, Mamulwar MS, Thakar MR. Fcrriiia Receptor Polymorphism Influences NK Cell Mediated ADCC Activity Against HIV. BMC Infect Dis (2019) 19(1):1053. doi: 10.1186/ s12879-019-4674-z

50. Connolly S, Wall KM, Tang J, Yu T, Kilembe W, Kijak G, et al. Fc-Gamma Receptor IIA and IIIA Variants in Two African Cohorts: Lack of Consistent Impact on Heterosexual HIV Acquisition, Viral Control, and Disease Progression. Virology (2018) 525:132-42. doi: 10.1016/.jvirol.2018.09.015

51. Descours B, Petitjean G, López-Zaragoza J-L, Bruel T, Raffel R, Psomas C, et al. CD32a is a Marker of a CD4 T-Cell HIV Reservoir Harbouring Replication-Competent Proviruses. Nature (2017) 543(7646):564-7. doi: 10.1038 /nature21710

52. Badia R, Ballana E, Castellví M, García-Vidal E, Pujantell M, Clotet B, et al. CD32 Expression is Associated to T-cell Activation and is Not a Marker of the HIV-1 Reservoir. Nat Commun (2018) 9(1):2739. doi: 10.1038/s41467-018-05157-w

53. Alvarez RA, Maestre AM, Law K, Durham ND, Barria MI, Ishii-Watabe A, et al. Enhanced FCGR2A and FCGR3A Signaling by HIV Viremic Controller Igg. JCI Insight (2017) 2(4):e88226-e. doi: 10.1172/jci.insight.88226

54. Li SS, Gilbert PB, Carpp LN, Pyo C-W, Janes H, Fong Y, et al. Fc Gamma Receptor Polymorphisms Modulated the Vaccine Effect on HIV-1 Risk in the HVTN 505 HIV Vaccine Trial. J Virol (2019) 93(21):e02041-18. doi: 10.1128/JVI.02041-18

55. Brouwer KC, Lal AA, Mirel LB, Otieno J, Ayisi J, Van Eijk AM, et al. Polymorphism of Fc Receptor IIa for Immunoglobulin G is Associated With Placental Malaria in HIV-1-Positive Women in Western Kenya. J Infect Dis (2004) 190(6):1192-8. doi: 10.1086/422850

56. Geraghty DE, Thorball CW, Fellay J, Thomas R. Effect of Fc Receptor Genetic Diversity on HIV-1 Disease Pathogenesis. Front Immunol (2019) 10 (970). doi: 10.3389/fimmu.2019.00970

57. Hans VM, Mehta DS, Hans M. Association of Fc Gamma-Receptors IIa, Iiia, and IIIb Genetic Polymorphism With Susceptibility to Chronic Periodontitis in South Indian Population. Contemp Clin Dentistry (2015) 6(Suppl 1):S1416. doi: 10.4103/0976-237X.166831

58. Parren P, Warmerdam P, Boeije L, Arts J, Westerdaal N, Vlug A, et al. On the Interaction of IgG Subclasses With the Low Affinity Fc Gamma RIIa (CD32) on Human Monocytes, Neutrophils, and Platelets. Analysis of a Functional Polymorphism to Human Igg2. J Clin Invest (1992) 90(4):153746. doi: 10.1172/JCI1 16022

59. Liu Y, Gao X, Masuda E, Redecha PB, Blank MC, Pricop L. Regulated Expression of Fcyr in Human Dendritic Cells Controls Cross-Presentation of Antigen-Antibody Complexes. J Immunol (2006) 177(12):8440-7. doi: 10.4049/jimmunol.177.12.8440

60. Prehn JL, Thomas LS, Landers CJ, Qi TY, Michelsen KS, Targan SR. The T Cell Costimulator TL1A is Induced by Fc $\gamma \mathrm{r}$ Signaling in Human Monocytes and Dendritic Cells. J Immunol (2007) 178(7):4033-8. doi: 10.4049/ jimmunol.178.7.4033

61. Stein M-P, Edberg JC, Kimberly RP, Mangan EK, Bharadwaj D, Mold C, et al. C-Reactive Protein Binding to Fcyriia on Human Monocytes and Neutrophils is Allele-Specific. J Clin Invest (2000) 105(3):369-76. doi: 10.1172/JCI7817

62. Weiser JN, Pan N, McGowan KL, Musher D, Martin A, Richards J. Phosphorylcholine on the Lipopolysaccharide of Haemophilus Influenzae Contributes to Persistence in the Respiratory Tract and Sensitivity to Serum Killing Mediated by C-reactive Protein. J Exp Med (1998) 187(4):631-40. doi: $10.1084 /$ jem.187.4.631
63. Hatjiharissi E, Xu L, Santos DD, Hunter ZR, Ciccarelli BT, Verselis S, et al. Increased Natural Killer Cell Expression of CD16, Augmented Binding and ADCC Activity to Rituximab Among Individuals Expressing the Fc\{gamma\} RIIIa-158 V/V and V/F Polymorphism. Blood (2007) 110(7):2561-4. doi: 10.1182/blood-2007-01-070656

64. Oboshi W, Watanabe T, Matsuyama Y, Kobara A, Yukimasa N, Ueno I, et al. The Influence of NK Cell-Mediated ADCC: Structure and Expression of the CD16 Molecule Differ Among Fcrriiia-V158F Genotypes in Healthy Japanese Subjects. Hum Immunol (2016) 77(2):165-71. doi: 10.1016/ j.humimm.2015.11.001

65. McLaren PJ, Coulonges C, Ripke S, Van Den Berg L, Buchbinder S, Carrington M, et al. Association Study of Common Genetic Variants and HIV-1 Acquisition in 6,300 Infected Cases and 7,200 Controls. PLoS Pathogens (2013) 9(7). doi: 10.1371/journal.ppat.1003515

66. Gaudinski MR, Coates EE, Houser KV, Chen GL, Yamshchikov G, Saunders JG, et al. Safety and Pharmacokinetics of the Fc-modified HIV-1 Human Monoclonal Antibody VRC01LS: A Phase 1 Open-Label Clinical Trial in Healthy Adults. PLoS Med (2018) 15(1):e1002493. doi: 10.1371/ journal.pmed.1002493

67. Bonsignori M, Pollara J, Moody MA, Alpert MD, Chen X, Hwang K-K, et al. Antibody-Dependent Cellular Cytotoxicity-Mediating Antibodies From an HIV-1 Vaccine Efficacy Trial Target Multiple Epitopes and Preferentially Use the VH1 Gene Family. J Virol (2012) 86(21):11521-32. doi: 10.1128/ JVI.01023-12

68. French MA, Tanaskovic S, Law MG, Lim A, Fernandez S, Ward LD, et al. Vaccine-Induced IgG2 anti-HIV p24 is Associated With Control of HIV in Patients With a 'High-Affinity' FcgammaRIIa Genotype. AIDS (London England) (2010) 24(13):1983-90. doi: 10.1097/QAD.0b013e32833c1ce0

69. Lu C-L, Murakowski DK, Bournazos S, Schoofs T, Sarkar D, HalperStromberg A, et al. Enhanced Clearance of HIV-1-infected Cells by Broadly Neutralizing Antibodies Against HIV-1 In Vivo. Science (New York NY) (2016) 352(6288):1001-4. doi: 10.1126/science.aaf1279

70. Malbec M, Porrot F, Rua R, Horwitz J, Klein F, Halper-Stromberg A, et al. Broadly Neutralizing Antibodies That Inhibit HIV-1 Cell to Cell Transmission. J Exp Med (2013) 210(13):2813-21. doi: 10.1084/jem.20131244

71. Williams WB, Liao H-X, Moody MA, Kepler TB, Alam SM, Gao F, et al. Diversion of HIV-1 Vaccine-Induced Immunity by gp41-microbiota CrossReactive Antibodies. Science (2015) 349(6249):aab1253. doi: 10.1126/ science.aab1253

72. Takeda A, Tuazon C, Ennis F. Antibody-Enhanced Infection by HIV-1 Via Fc Receptor-Mediated Entry. Science (1988) 242(4878):580-3. doi: 10.1126/ science. 2972065

73. Homsy J, Meyer M, Tateno M, Clarkson S, Levy J. The Fc and Not CD4 Receptor Mediates Antibody Enhancement of HIV Infection in Human Cells. Science (1989) 244(4910):1357-60. doi: 10.1126/science.2786647

74. Doyle T, Goujon C, Malim MH. HIV-1 and Interferons: Who's Interfering With Whom? Nat Rev Microbiol (2015) 13(7):403-13. doi: 10.1038/ nrmicro3449

75. Newling M, Hoepel W, Vogelpoel LTC, Heineke MH, van Burgsteden JA, Taanman-Kueter EWM, et al. Fc Gamma Receptor IIa Suppresses Type I and III Interferon Production by Human Myeloid Immune Cells. Eur J Immunol (2018) 48(11):1796-809. doi: 10.1002/eji.201847615

76. Ackerman ME, Crispin M, Yu X, Baruah K, Boesch AW, Harvey DJ, et al. Natural Variation in Fc Glycosylation of HIV-specific Antibodies Impacts Antiviral Activity. J Clin Invest (2013) 123(5):2183-92. doi: 10.1172/JCI65708

77. Ackerman ME, Dugast A-S, McAndrew EG, Tsoukas S, Licht AF, Irvine DJ, et al. Enhanced Phagocytic Activity of HIV-specific Antibodies Correlates With Natural Production of Immunoglobulins With Skewed Affinity for Fcrr2a and Fcrr2b. J Virol (2013) 87(10):5468-76. doi: 10.1128/JVI.03403-12

78. De Souza MS, Phanuphak N, Pinyakorn S, Trichavaroj R, Pattanachaiwit S, Chomchey N, et al. Impact of Nucleic Acid Testing Relative to Antigen/ Antibody Combination Immunoassay on the Detection of Acute HIV Infection. Aids (2015) 29(7):793-800. doi: 10.1097/QAD. 0000000000000616

79. Ananworanich J, Fletcher JL, Pinyakorn S, Van Griensven F, Vandergeeten C, Schuetz A, et al. A Novel Acute HIV Infection Staging System Based on 4 Th Generation Immunoassay. Retrovirology (2013) 10(1):56. doi: 10.1186/ 1742-4690-10-56 
80. Machado LR, Bowdrey J, Ngaimisi E, Habtewold A, Minzi O, Makonnen E, et al. Copy Number Variation of Fc Gamma Receptor Genes in HIVInfected and HIV-Tuberculosis Co-Infected Individuals in Sub-Saharan Africa. PLoS One (2013) 8(11):e78165. doi: 10.1371/journal.pone.0078165

81. Adu B, Dodoo D, Adukpo S, Hedley PL, Arthur F, Gerds TA, et al. Fc Gamma Receptor IIIB (FcgammaRIIIB) Polymorphisms are Associated With Clinical Malaria in Ghanaian Children. PLoS One (2012) 7(9): e46197. doi: 10.1371/journal.pone.0046197

82. Osborne JM, Chacko GW, Brandt JT, Anderson CL. Ethnic Variation in Frequency of an Allelic Polymorphism of Human Fc $\gamma$ RIIA Determined With Allele Specific Oligonucleotide Probes. J Immunol Methods (1994) 173 (2):207-17. doi: 10.1016/0022-1759(94)90299-2

83. van Schie RC, Wilson ME. Evaluation of Human Fcyriia (CD32) and Fcrriiib (CD16) Polymorphisms in Caucasians and African-Americans Using Salivary DNA. Clin Diagn Lab Immunol (2000) 7(4):676-81. doi: 10.1128/ CDLI.7.4.676-681.2000

84. Tong Y, Jin J, Yan L, Neppert J, Marget M, Flesch BK. FCGR3B Gene Frequencies and FCGR3 Variants in a Chinese Population From Zhejiang Province. Ann Hematol (2003) 82(9):574-8. doi: 10.1007/s00277-003-0725-y

85. Kaset C, Leetrakool N, Intharanut K, Nathalang O. Frequency of FCGR3B Alleles in Thai Blood Donors. Ann Lab Med (2013) 33(6):426-30. doi: 10.3343/alm.2013.33.6.426

86. Burton DR, Hessell AJ, Keele BF, Klasse PJ, Ketas TA, Moldt B, et al. Limited or No Protection by Weakly or Nonneutralizing Antibodies Against Vaginal SHIV Challenge of Macaques Compared With a Strongly Neutralizing Antibody. Proc Natl Acad Sci (2011) 108(27):11181-6. doi: 10.1073/ pnas. 1103012108

87. Bashirova AA, Thomas R, Carrington M. HLA/KIR Restraint of HIV: Surviving the Fittest. Annu Rev Immunol (2011) 29:295-317. doi: 10.1146/ annurev-immunol-031210-101332

88. McLaren PJ, Carrington M. The Impact of Host Genetic Variation on Infection With HIV-1. Nat Immunol (2015) 16(6):577. doi: 10.1038/ni.3147

89. Buzon MJ, Martin-Gayo E, Pereyra F, Ouyang Z, Sun H, Li JZ, et al. LongTerm Antiretroviral Treatment Initiated At Primary HIV-1 Infection Affects the Size, Composition, and Decay Kinetics of the Reservoir of HIV-1infected Cd4 T Cells. J Virol (2014) 88(17):10056-65. doi: 10.1128/ JVI.01046-14

90. Deeks SG, Lewin SR, Ross AL, Ananworanich J, Benkirane M, Cannon P, et al. International AIDS Society Global Scientific Strategy: Towards an HIV Cure 2016. Nat Med (2016) 22(8):839. doi: 10.1038/nm.4108

91. Williams JP, Hurst J, Stöhr W, Robinson N, Brown H, Fisher M, et al. Hiv-1 DNA Predicts Disease Progression and Post-Treatment Virological Control. eLife (2014) 3:e03821. doi: 10.7554/eLife.03821

92. Fourati S, Flandre P, Calin R, Carcelain G, Soulie C, Lambert-Niclot S, et al. Factors Associated With a Low HIV Reservoir in Patients With Prolonged Suppressive Antiretroviral Therapy. J Antimicrobial Chemother (2013) 69 (3):753-6. doi: 10.1093/jac/dkt428

93. Martin GE, Pace M, Thornhill JP, Phetsouphanh C, Meyerowitz J, Gossez M, et al. Cd32-Expressing Cd4 T Cells Are Phenotypically Diverse and Can Contain Proviral Hiv Dna. Front Immunol (2018) 9(928). doi: 10.3389/ fimmu.2018.00928

94. Abdel-Mohsen M, Kuri-Cervantes L, Grau-Exposito J, Spivak AM, Nell RA, Tomescu C, et al. CD32 is Expressed on Cells With Transcriptionally Active HIV But Does Not Enrich for HIV DNA in Resting T Cells. Sci Trans Med (2018) 10(437). doi: 10.1126/scitranslmed.aar6759

95. Pérez L, Anderson J, Chipman J, Thorkelson A, Chun T-W, Moir S, et al. Conflicting Evidence for HIV Enrichment in CD32+ Cd4 T Cells. Nature (2018) 561(7723):E9-16. doi: 10.1038/s41586-018-0493-4

96. Osuna CE, Lim S-Y, Kublin JL, Apps R, Chen E, Mota TM, et al. Evidence That CD32a Does Not Mark the HIV-1 Latent Reservoir. Nature (2018) 561 (7723):E20-E8. doi: 10.1038/s41586-018-0495-2

97. Bertagnolli LN, White JA, Simonetti FR, Beg SA, Lai J, Tomescu C, et al. The Role of CD32 During HIV-1 Infection. Nature (2018) 561(7723):E17-9. doi: 10.1038/s41586-018-0494-3

98. Thornhill JP, Pace M, Martin GE, Hoare J, Peake S, Herrera C, et al. CD32 Expressing Doublets in HIV-infected Gut-Associated Lymphoid Tissue are Associated With a T Follicular Helper Cell Phenotype. Mucosal Immunol (2019) 12(5):1212-9. doi: 10.1038/s41385-019-0180-2
99. Darcis G, Binda CS, Klaver B, Herrera-Carrillo E, Berkhout B, Das AT. The Impact of HIV-1 Genetic Diversity on CRISPR-Cas9 Antiviral Activity and Viral Escape. Viruses (2019) 11(3):255. doi: 10.3390/v11030255

100. Darcis G, Kootstra NA, Hooibrink B, van Montfort T, Maurer I, Groen K. CD32+ CD4+ T cells are highly enriched for HIV DNA and can support transcriptional latency. Cell Rep (2020) 30(7):2284-96. doi: 10.1016/ j.celrep.2020.01.071

101. Ananworanich J, Chomont N, Eller LA, Kroon E, Tovanabutra S, Bose M, et al. Hiv DNA Set Point is Rapidly Established in Acute HIV Infection and Dramatically Reduced by Early ART. EBioMedicine (2016) 11:68-72. doi: 10.1016/j.ebiom.2016.07.024

102. A Pasternak, J Prins, B Berkhout eds. Cell-Associated HIV-1 Unspliced RNA Level Predicts Both Time to Virological Suppression and Duration of Post-Treatment Virological Control in Patients Treated With Temporary Early ART. Journal OF the INTERNATIONAL Aids Society. GENEVA, 1202, SWITZERLAND: INT AIDS SOCIETY AVENUE DE FRANCE 23 (2016). doi: 10.1016/S2055-6640(20)31009-8

103. Eisele E, Siliciano RF. Redefining the Viral Reservoirs That Prevent HIV-1 Eradication. Immunity (2012) 37(3):377-88. doi: 10.1016/j.immuni.2012.08.010

104. Hogan LE, Vasquez J, Hobbs KS, Hanhauser E, Aguilar-Rodriguez B, Hussien R, et al. Increased HIV-1 Transcriptional Activity and Infectious Burden in Peripheral Blood and Gut-Associated CD4+ T Cells Expressing CD30. PLoS Pathogens (2018) 14(2). doi: 10.1371/journal.ppat.1006856

105. Noto A, Procopio FA, Banga R, Suffiotti M, Corpataux J-M, Cavassini M, et al. CD32+ and PD-1+ Lymph Node CD4 T Cells Support Persistent HIV-1 Transcription in Treated Aviremic Individuals. J Virol (2018) 92(20): e00901-18. doi: 10.1128/JVI.00901-18

106. Deepe RN, Kistner-Griffin E, Martin JN, Deeks SG, Pandey JP. Epistatic Interactions Between $\mathrm{Fc}(\mathrm{GM})$ and $\mathrm{Fc} \gamma \mathrm{r}$ Genes and the Host Control of Human Immunodeficiency Virus Replication. Hum Immunol (2012) 73 (3):263-6. doi: 10.1016/j.humimm.2011.12.008

107. Carapito R, Mayr L, Molitor A, Verniquet M, Schmidt S, Tahar O, et al. A Fc $\gamma$ RIIa Polymorphism has a HLA-B57 and HLA-B27 Independent Effect on HIV Disease Outcome. Genes Immun (2020) 21(4):263-8. doi: 10.1038/ s41435-020-0106-8

108. Altfeld M, Addo MM, Rosenberg ES, Hecht FM, Lee PK, Vogel M, et al. Influence of HLA-B57 on Clinical Presentation and Viral Control During Acute HIV-1 Infection. Aids (2003) 17(18):2581-91. doi: 10.1097/00002030200312050-00005

109. Neumann-Haefelin C. Hla-B27-mediated Protection in HIV and Hepatitis C Virus Infection and Pathogenesis in Spondyloarthritis: Two Sides of the Same Coin? Curr Opin Rheumatol (2013) 25(4):426-33. doi: 10.1097/ BOR.0b013e328362018f

110. Tomaras GD, Ferrari G, Shen X, Alam SM, Liao H-X, Pollara J, et al. Vaccine-Induced Plasma IgA Specific for the C1 Region of the HIV-1 Envelope Blocks Binding and Effector Function of Igg. Proc Natl Acad Sci U S A (2013) 110(22):9019-24. doi: 10.1073/pnas.1301456110

111. Zolla-Pazner S, deCamp AC, Cardozo T, Karasavvas N, Gottardo R, Williams C, et al. Analysis of V2 Antibody Responses Induced in Vaccinees in the ALVAC/AIDSVAX HIV-1 Vaccine Efficacy Trial. PLoS One (2013) 8(1):e53629. doi: 10.1371/journal.pone.0053629

112. Zolla-Pazner S, DeCamp A, Gilbert PB, Williams C, Yates NL, Williams WT, et al. Vaccine-Induced IgG Antibodies to V1V2 Regions of Multiple HIV-1 Subtypes Correlate With Decreased Risk of HIV-1 Infection. PLoS One (2014) 9(2):e87572. doi: 10.1371/journal.pone.0087572

113. Chung AW, Ghebremichael M, Robinson H, Brown E, Choi I, Lane S, et al. Polyfunctional Fc-Effector Profiles Mediated by IgG Subclass Selection Distinguish RV144 and VAX003 Vaccines. Sci Trans Med (2014) 6 (228):228ra38-ra38. doi: 10.1126/scitranslmed.3007736

114. Yates NL, Liao H-X, Fong Y, DeCamp A, Vandergrift NA, Williams WT, et al. Vaccine-Induced Env V1-V2 IgG3 Correlates With Lower HIV-1 Infection Risk and Declines Soon After Vaccination. Sci Trans Med (2014) 6 (228):228ra39-ra39. doi: 10.1126/scitranslmed.3007730

115. Haynes BF, Gilbert PB, McElrath MJ, Zolla-Pazner S, Tomaras GD, Alam SM, et al. Immune-Correlates Analysis of an HIV-1 Vaccine Efficacy Trial. N Engl J Med (2012) 366(14):1275-86. doi: 10.1056/NEJMoa1113425

116. Liao H-X, Bonsignori M, Alam SM, McLellan JS, Tomaras GD, Moody $\mathrm{MA}$, et al. Vaccine Induction of Antibodies Against a Structurally 
Heterogeneous Site of Immune Pressure Within HIV-1 Envelope Protein Variable Regions 1 and 2. Immunity (2013) 38(1):176-86. doi: 10.1016/ j.immuni.2012.11.011

117. Bournazos S, DiLillo DJ, Ravetch JV. Humanized Mice to Study Fc $\gamma R$ Function. In: M Daeron, F Nimmerjahn, editors. Fc Receptors. Current Topics in Microbiology and Immunology, vol 382. Springer, Cham (2014). doi: 10.1007/978-3-319-07911-0_11

118. Hessell AJ, Hangartner L, Hunter M, Havenith CE, Beurskens FJ, Bakker JM, et al. Fc Receptor But Not Complement Binding is Important in Antibody Protection Against HIV. Nature (2007) 449(7158):101-4. doi: 10.1038/ nature06106

119. Hessell AJ, Rakasz EG, Poignard P, Hangartner L, Landucci G, Forthal DN, et al. Broadly Neutralizing Human anti-HIV Antibody 2G12 is Effective in Protection Against Mucosal SHIV Challenge Even At Low Serum Neutralizing Titers. PLoS Pathog (2009) 5(5):e1000433. doi: 10.1371/ journal.ppat.1000433

120. Parsons MS, Lee WS, Kristensen AB, Amarasena T, Khoury G, Wheatley AK, et al. Fc-Dependent Functions are Redundant to Efficacy of anti-HIV Antibody PGT121 in Macaques. J Clin Invest (2019) 129(1):182-91. doi: 10.1172/JCI122466

121. Abela IA, Berlinger L, Schanz M, Reynell L, Günthard HF, Rusert P, et al. Cell-Cell Transmission Enables HIV-1 to Evade Inhibition by Potent CD4bs Directed Antibodies. PLoS Pathogens (2012) 8(4). doi: 10.1371/ journal.ppat.1002634

122. Chung AW, Navis M, Isitman G, Wren L, Silvers J, Amin J, et al. Activation of NK Cells by ADCC Antibodies and HIV Disease Progression. J Acquired Immune Deficiency Syndromes (2011) 58(2):127. doi: 10.1097/QAI. 0b013e31822c62b9

123. Balazs AB, Chen J, Hong CM, Rao DS, Yang L, Baltimore D. Antibody-Based Protection Against HIV Infection by Vectored Immunoprophylaxis. Nature (2012) 481(7379):81-4. doi: 10.1038/nature10660

124. Emery S, Kelleher AD, Workman C, Puls RL, Bloch M, Baker D, et al. Influence of IFNgamma Co-Expression on the Safety and Antiviral Efficacy of Recombinant Fowlpox Virus HIV Therapeutic Vaccines Following Interruption of Antiretroviral Therapy. Hum Vaccines (2007) 3(6):260-7. doi: $10.4161 / \mathrm{hv} .4627$

125. Emery S, Workman C, Puls RL, Bloch M, Baker D, Bodsworth N, et al. Randomised, Placebo-Controlled, Phase I/IIa Evaluation of the Safety and Immunogenicity of Fowlpox Virus Expressing HIV Gag-Pol and Interferon? in HIV-1 Infected Subjects. Hum Vaccines (2005) 1(6):232-8. doi: 10.4161/ hv.1.6.2342

126. Ananworanich J. What Will it Take to Cure HIV? Topics Antiviral Med (2015) 23(2):80.

127. Battistini A, Sgarbanti M. HIV-1 Latency: An Update of Molecular Mechanisms and Therapeutic Strategies. Viruses (2014) 6(4):1715-58. doi: $10.3390 / v 6041715$

128. Barton KM, Burch BD, Soriano-Sarabia N, Margolis DM. Prospects for Treatment of Latent HIV. Clin Pharmacol Ther (2013) 93(1):46-56. doi: 10.1038/clpt.2012.202

129. Archin NM, Margolis DM. Emerging Strategies to Deplete the HIV Reservoir. Curr Opin Infect Dis (2014) 27(1):29. doi: 10.1097/QCO.0000000000000026

130. Darcis G, Van Driessche B, Van Lint C. Preclinical Shock Strategies to Reactivate Latent HIV-1: An Update. Curr Opin HIV AIDS (2016) 11 (4):388-93. doi: 10.1097/COH.0000000000000288

131. Darcis G, Van Driessche B, Van Lint C. HIV Latency: Should We Shock or Lock? Trends Immunol (2017) 38(3):217-28. doi: 10.1016/j.it.2016.12.003

132. Albert BJ, Niu A, Ramani R, Marshall GR, Wender PA, Williams RM, et al. Combinations of Isoform-Targeted Histone Deacetylase Inhibitors and Bryostatin Analogues Display Remarkable Potency to Activate Latent HIV Without Global T-cell Activation. Sci Rep (2017) 7(1):7456. doi: 10.1038/s41598-017-07814-4

133. Bournazos S, Klein F, Pietzsch J, Seaman MS, Nussenzweig MC, Ravetch JV. Broadly Neutralizing anti-HIV-1 Antibodies Require Fc Effector Functions for In Vivo Activity. Cell (2014) 158(6):1243-53. doi: 10.1016/j.cell.2014.08.023

134. Barouch DH, Whitney JB, Moldt B, Klein F, Oliveira TY, Liu J, et al. Therapeutic Efficacy of Potent Neutralizing HIV-1-specific Monoclonal Antibodies in SHIV-infected Rhesus Monkeys. Nature (2013) 503 (7475):224-8. doi: 10.1038/nature12744
135. Parsons MS, Lloyd SB, Lee WS, Kristensen AB, Amarasena T, Center RJ, et al. Partial Efficacy of a Broadly Neutralizing Antibody Against CellAssociated SHIV Infection. Sci Trans Med (2017) 9(402). doi: 10.1126/ scitranslmed.aaf 1483

136. Moldt B, Rakasz EG, Schultz N, Chan-Hui P-Y, Swiderek K, Weisgrau KL, et al. Highly Potent HIV-specific Antibody Neutralization In Vitro Translates Into Effective Protection Against Mucosal SHIV Challenge In Vivo. Proc Natl Acad Sci (2012) 109(46):18921-5. doi: 10.1073/ pnas. 1214785109

137. Chen P, Hübner W, Spinelli MA, Chen BK. Predominant Mode of Human Immunodeficiency Virus Transfer Between T Cells is Mediated by Sustained Env-dependent Neutralization-Resistant Virological Synapses. J Virol (2007) 81(22):12582-95. doi: 10.1128/JVI.00381-07

138. Ganesh L, Leung K, Lore K, Levin R, Panet A, Schwartz O, et al. Infection of Specific Dendritic Cells by CCR5-tropic Human Immunodeficiency Virus Type 1 Promotes Cell-Mediated Transmission of Virus Resistant to Broadly Neutralizing Antibodies. J Virol (2004) 78(21):11980-7. doi: 10.1128/ JVI.78.21.11980-11987.2004

139. Kong R, Louder MK, Wagh K, Bailer RT, deCamp A, Greene K, et al. Improving Neutralization Potency and Breadth by Combining Broadly Reactive HIV-1 Antibodies Targeting Major Neutralization Epitopes. J Virol (2015) 89(5):2659-71. doi: 10.1128/JVI.03136-14

140. Mayr LM, Su B, Moog C. Non-Neutralizing Antibodies Directed Against HIV and Their Functions. Front Immunol (2017) 8:1590-. doi: 10.3389/ fimmu.2017.01590

141. Martin N, Welsch S, Jolly C, Briggs JA, Vaux D, Sattentau QJ. Virological Synapse-Mediated Spread of Human Immunodeficiency Virus Type 1 Between T Cells is Sensitive to Entry Inhibition. J Virol (2010) 84(7):351627. doi: 10.1128/JVI.02651-09

142. Su B, Lederle A, Laumond G, Ducloy C, Schmidt S, Decoville T, et al. Broadly Neutralizing Antibody VRC01 Prevents HIV-1 Transmission From Plasmacytoid Dendritic Cells to CD4 T Lymphocytes. J Virol (2014) 88 (18):10975-81. doi: 10.1128/JVI.01748-14

143. Su B, Peressin M, Ducloy C, Penichon J, Mayr LM, Laumond G, et al. Short Communication: Exploring Antibody Potential as Prophylactic/Therapeutic Strategies for Prevention of Early Mucosal HIV-1 Infection. AIDS Res Hum Retroviruses (2015) 31(11):1187-91. doi: 10.1089/aid.2015.0041

144. Li H, Zony C, Chen P, Chen BK. Reduced Potency and Incomplete Neutralization of Broadly Neutralizing Antibodies Against Cell-to-Cell Transmission of HIV-1 With Transmitted Founder Envs. J Virol (2017) 91 (9):e02425-16. doi: 10.1128/JVI.02425-16

145. Duncan CJ, Russell RA, Sattentau QJ. High Multiplicity HIV-1 Cell-to-Cell Transmission From Macrophages to CD4+ T Cells Limits Antiretroviral Efficacy. Aids (2013) 27(14):2201-6. doi: 10.1097/QAD.0b013e3283632ec4

146. Richardson SI, Chung AW, Natarajan H, Mabvakure B, Mkhize NN, Garrett N, et al. HIV-Specific Fc Effector Function Early in Infection Predicts the Development of Broadly Neutralizing Antibodies. PLoS Pathogens (2018) 14(4):e1006987. doi: 10.1371/journal.ppat.1006987

147. Lehrnbecher T, Foster CB, Zhu S, Leitman SF, Goldin LR, Huppi K, et al. Variant Genotypes of the Low-Affinity Fcy Receptors in Two Control Populations and a Review of Low-Affinity Fcy Receptor Polymorphisms in Control and Disease Populations. Blood J Am Soc Hematol (1999) 94(12):422032. doi: 10.1182/blood.V94.12.4220.424k08_4220_4232

148. Israelsson E, Vafa M, Maiga B, Lysén A, Iriemenam NC, Dolo A, et al. Differences in Fcgamma Receptor IIa Genotypes and IgG Subclass Pattern of Anti-Malarial Antibodies Between Sympatric Ethnic Groups in Mali. Malaria J (2008) 7(1):175. doi: 10.1186/1475-2875-7-175

Conflict of Interest: The authors declare that the research was conducted in the absence of any commercial or financial relationships that could be construed as a potential conflict of interest.

Copyright (๑) 2021 Lamptey, Bonney, Adu and Kyei. This is an open-access article distributed under the terms of the Creative Commons Attribution License (CC BY). The use, distribution or reproduction in other forums is permitted, provided the original author(s) and the copyright owner(s) are credited and that the original publication in this journal is cited, in accordance with accepted academic practice. No use, distribution or reproduction is permitted which does not comply with these terms. 